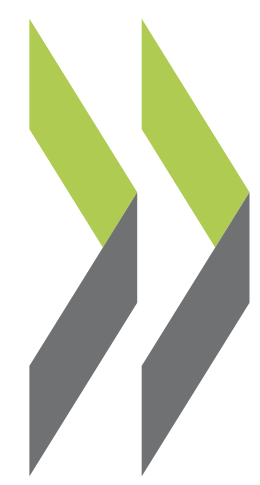

OECD Economics Department Working Papers No. 1381

Improving the allocation and efficiency of public Patrice Ollivaud spending in Indonesia 
Organisation de Coopération et de Développement Économiques

Organisation for Economic Co-operation and Development

04-Apr-2017

ECONOMICS DEPARTMENT

English - Or. English

Cancels \& replaces the same document of 03 April 2017

\section{IMPROVING THE ALLOCATION AND EFFICIENCY OF PUBLIC SPENDING IN INDONESIA}

ECONOMICS DEPARTMENT WORKING PAPERS No. 1381

\section{By Patrice Ollivaud}

OECD Working Papers should not be reported as representing the official views of the OECD or of its member countries. The opinions expressed and arguments employed are those of the author(s).

Authorised for publication by Alvaro Pereira, Director, Country Studies Branch, Economics Department.

All Economics Department Working Papers are available at www.oecd.org/eco/workingpapers.

\section{JT03411956}

Complete document available on OLIS in its original format

This document and any map included herein are without prejudice to the status of or sovereignty over any territory, to the delimitation of international frontiers and boundaries and to the name of any territory, city or area. 
OECD Working Papers should not be reported as representing the official views of the OECD or of its member countries. The opinions expressed and arguments employed are those of the author(s).

Working Papers describe preliminary results or research in progress by the author(s) and are published to stimulate discussion on a broad range of issues on which the OECD works.

Comments on Working Papers are welcomed, and may be sent to OECD Economics Department, 2 rue André-Pascal, 75775 Paris Cedex 16, France, or by e-mail to eco.contact@oecd.org.

All Economics Department Working Papers are available at. www.oecd.org/eco/workingpapers

This document and any map included herein are without prejudice to the status of or sovereignty over any territory, to the delimitation of international frontiers and boundaries and to the name of any territory, city or area.

The statistical data for Israel are supplied by and under the responsibility of the relevant Israeli authorities. The use of such data by the OECD is without prejudice to the status of the Golan Heights, East Jerusalem and Israeli settlements in the West Bank under the terms of international law.

Latvia was not an OECD Member at the time of preparation of this publication. Accordingly, Latvia does not appear in the list of OECD Members and is not included in the zone aggregates.

\section{(C) OECD (2017)}

You can copy, download or print OECD content for your own use, and you can include excerpts from OECD publications, databases and multimedia products in your own documents, presentations, blogs, websites and teaching materials, provided that suitable acknowledgment of OECD as source and copyright owner is given. All requests for commercial use and translation rights should be submitted to rights@oecd.org 
ECO/WKP(2017)13

\section{ABSTRACT/RÉSUMÉ \\ Improving the allocation and efficiency of public spending in Indonesia}

Indonesia's fiscal position is generally sound and policy making prudent. However, the country still faces important challenges in terms of economic and social development. Infrastructure, education, health and social security are all spending areas that the government is trying to improve further, because the nation has yet to converge to the superior outcomes achieved by other countries at a similar level of development. The government's size is small, and raising more revenues will take time, which forces the authorities to get the most out of existing resources and prioritise enhancing the efficiency of public spending. To achieve such an improvement a whole-of-government approach is required, including in the budgeting process and in the establishment of medium-term goals. A key element of Indonesia's recent history lies in the tremendous efforts as from the late 1990s to go from a very centralised system of governance towards one with several nested levels of government. According to some metrics it was a success. Nonetheless, despite the considerable resources already devoted to decentralisation, there is still ample room for improvement in terms of coordination, transparency, accountability and service provision. More broadly, moving away from spending objectives and adopting performance-based incentives would lift outcomes. At the national level, Indonesia would also benefit from scrapping a certain number of inefficient expenditures, such as energy and fertiliser subsidies, and from concentrating on those policies with the highest payoffs, like filling infrastructure gaps and expanding conditional cash transfer schemes. While public employment, especially by some subnational governments, could be streamlined, improving its capacity should be the focus, including for teachers. The fight against corruption should continue by all available means, in particular with a more generalised use of electronic public procurement.

This Working Paper relates to the 2016 OECD Economic Survey of Indonesia (www.oecd.org/eco/surveys/economic-survey-indonesia.htm).

JEL codes: E61; H11; H50; H70; I18; I28

Keywords: public spending; efficiency; effectiveness; Indonesia; government expenditures

$* * * * *$

Améliorer l'affectation des dépenses publiques et leur efficience en Indonésie

La situation budgétaire de l'Indonésie est dans l'ensemble solide et la politique en la matière prudente. Mais celle-ci est toujours confrontée à d'importantes difficultés dans le domaine du développement économique et social. Les infrastructures, l'éducation, la santé et la sécurité sociale sont autant de domaines dans lesquels les pouvoirs publics s'efforcent d'améliorer encore les dépenses, car il faut que l'Indonésie parvienne à égaler les bien meilleurs résultats qu'enregistrent d'autres pays dont le niveau de développement est analogue. La taille du secteur public est peu importante et l'augmentation des recettes de l'État prendra du temps, ce qui contraint les autorités à faire une utilisation optimale des ressources existantes et à privilégier le renforcement de l'efficience des dépenses publiques. Pour progresser dans ce sens, il est nécessaire d'adopter une approche faisant appel à l'ensemble de l'administration, notamment pour le processus d'établissement du budget et la définition des objectifs à moyen terme. L'histoire récente de l'Indonésie a été particulièrement marquée par les efforts considérables qui ont été déployés à partir de la fin des années 1990 pour passer d'un système de gouvernance très centralisé à un système constitué de plusieurs niveaux d'administration imbriqués les uns dans les autres. Selon certains indicateurs, ces efforts ont été fructueux. Toutefois, malgré l'importance des ressources qui ont déjà été consacrées à la décentralisation, il y a encore beaucoup de progrès à faire sur le plan de la coordination, de la transparence, de la redevabilité et de la fourniture des services. D'une manière plus générale, l'abandon progressif des objectifs de dépenses et l'adoption d'un système d'incitation fondé sur les performances permettraient d'améliorer les résultats. Au niveau national, l'Indonésie gagnerait aussi à supprimer un certain nombre de dépenses inefficientes, comme les subventions à l'énergie et aux engrais, ainsi qu'à concentrer son attention sur les politiques qui donnent les meilleurs résultats, comme celles qui visent à combler le déficit d'infrastructures et développer les dispositifs de transferts monétaires conditionnels. S'il est vrai que l'emploi public pourrait être rationalisé, surtout dans certaines administrations infranationales, la priorité devrait être donnée à l'amélioration des capacités des fonctionnaires, notamment des enseignants. La lutte contre la corruption devrait être poursuivie par tous les moyens possibles, en particulier à travers une généralisation plus grande de la passation électronique des marchés publics.

$\mathrm{Ce}$ Document de travail se rapporte à l'Étude économique de l'OCDE de l'Indonésie, 2016 (www.oecd.org/fr/eco/etudes/etude-economique-indonesie.htm).

Classfication JEL : E61 ; H11 ; H50 ; H70 ; I18 ; I28

Mots-clés : dépenses publiques ; efficience ; efficacité ; Indonésie 


\section{TABLE OF CONTENTS}

Introduction...
Government's role in development: huge improvements, but important gaps remain
Raising revenues will take time
Government public finance
Budget formulation and execution
Governance
Enhancing the decentralisation approach
Improving public procurement
Streamlining subsidies
Energy
Pilling infrastructure gaps in a tight budgetary context
Personnel spending .

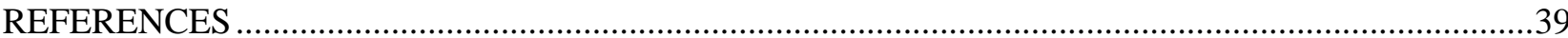

\section{Tables}

1. Breakdown of central government transfers to sub-national governments by type

\section{Figures}

Figure 1 General government spending and real GDP, 2014 or nearest year ..........................................6

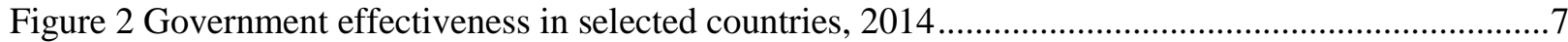

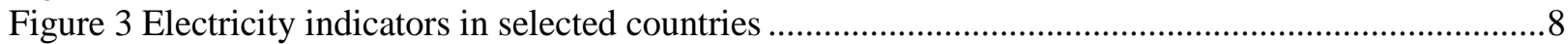

Figure 4 Selected indicators on health and education for Indonesia over a long period...............................

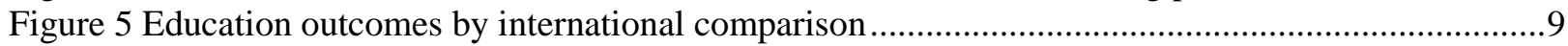

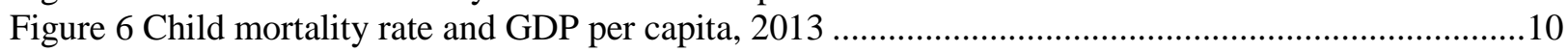

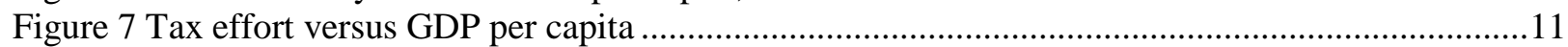

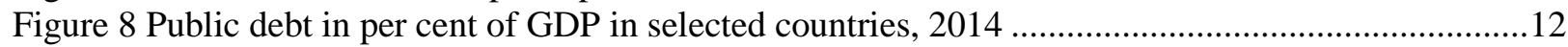

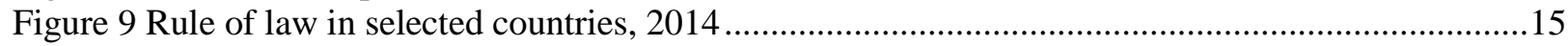

Figure 10 Statistical capacity in selected countries ............................................................................17

Figure 11 Central government spending and transfers to the regions.................................................18

Figure 12 Regional spending breakdown and public employment density ...........................................19

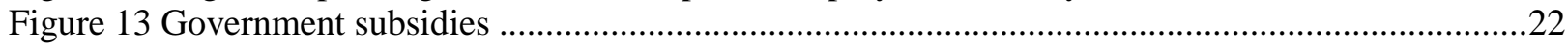

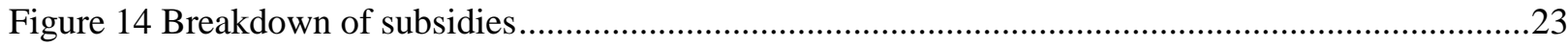




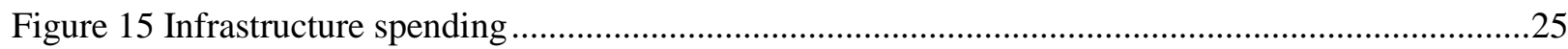

Figure 16 Public-private partnership capital stock in selected countries, 2013 .....................................26

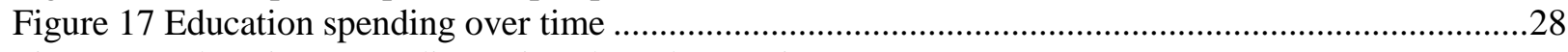

Figure 18 Education expenditures in selected countries, 2013 or nearest year.......................................29

Figure 19 Spending by level of education in selected countries, 2013 or nearest year ...............................30

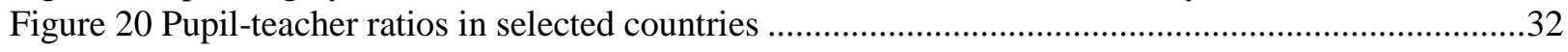

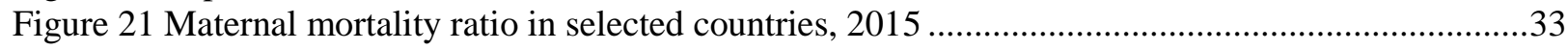

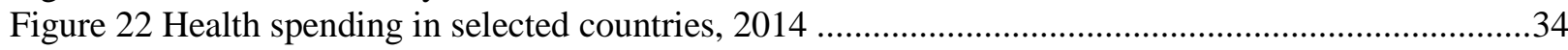

Figure 23 Health service indicators in selected countries, 2012 or nearest year ......................................36

Figure 24 Poverty rate in selected countries, 2014 or nearest................................................................37

Figure 25 Public expenditures on social assistance in selected countries, 2012 or nearest year ................37

\section{Boxes}

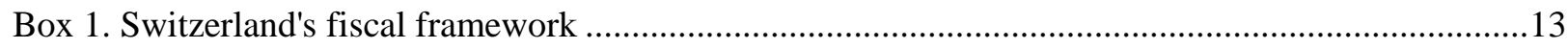

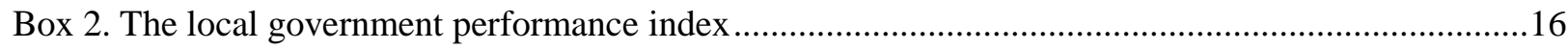




\title{
IMPROVING THE ALLOCATION AND EFFICIENCY OF PUBLIC SPENDING IN INDONESIA
}

\author{
Patrice Ollivaud $^{1}$
}

\section{Introduction}

By international comparison, government spending as a share of GDP is low in Indonesia, even when taking into account its level of development (Figure 1). The size of government depends on country characteristics, but the role of the public sector is crucial in the process of development, particularly in providing a social safety net, health, education and public infrastructure at an optimal cost. A wellfunctioning public sector is also essential for private-sector economic performance (Knox Lovell, 2002). To some extent, revenues during the commodity super-cycle and relatively high GDP growth mitigated the need for such a focus. In the future, however, budget pressures could become substantial which notably raises the need to address important administration costs that are absorbing a significant share of government revenues.

Figure 1. General government spending and real GDP, 2014 or nearest year

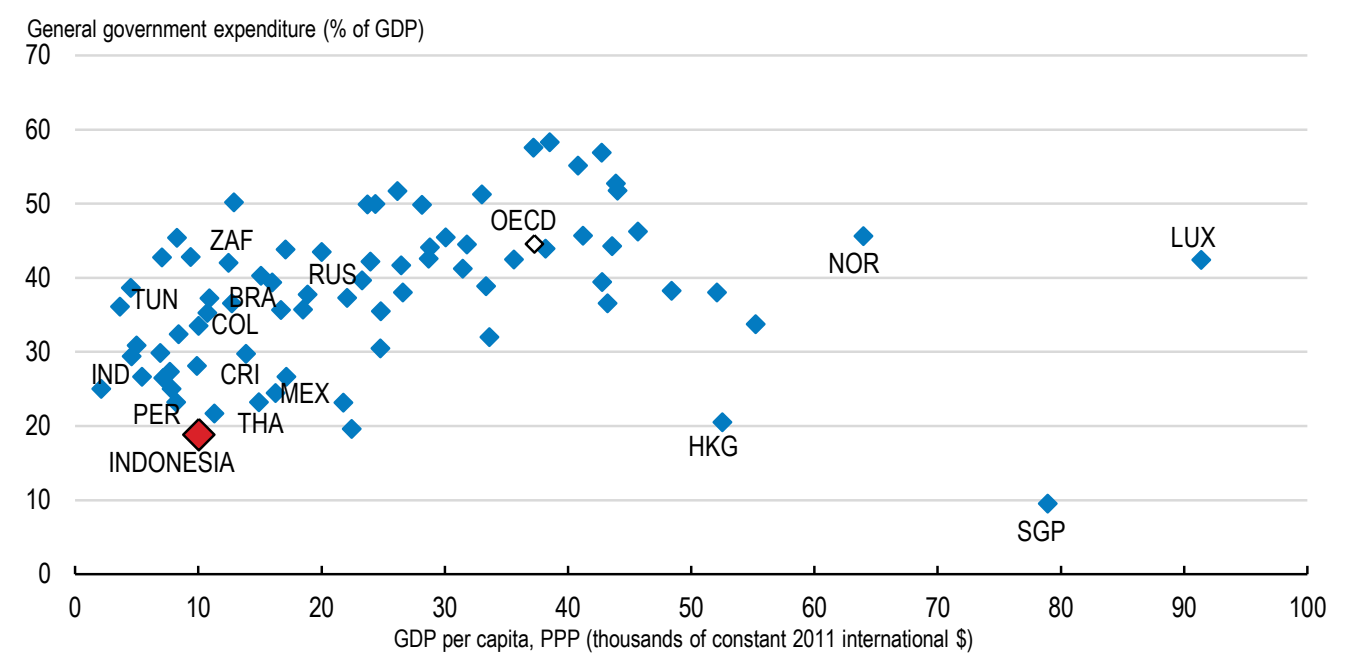

Source: OECD. Government at a Glance; IMF. Government Finance Statistics; World Bank. World Development Indicators.

The quality of public governance, as measured by the World Bank estimate of government effectiveness, puts Indonesia well behind countries like the Philippines, Thailand, Malaysia, Viet Nam and Singapore (Figure 2). This suggests that Indonesia still has room to improve the quality of public services, even before addressing the question of raising more revenues. Indeed, it suffers from a certain number of gaps

\footnotetext{
${ }^{1}$ The author is member of the Economics Department of the OECD. He thanks Peter Hoeller, Peter Jarrett, Asa Johansson, Christine Lewis and Petar Vujanovic (all of whom are members of the Economics Department) for comments and suggestions. The paper has also benefitted from comments by Indonesian officials and by members of the OECD Economic Development Review Committee. Special thanks go to Anne Legendre for statistical assistance and Dacil Kurzweg (also from the Economics Department) for assistance in preparing this document.
} 
and weaknesses that hinder its development, including in providing such basic public services as sanitation, water, education and health. The extent of those challenges, together with the existence of a demographic dividend (nearly half of its population is below 25), suggests that the government should make the most of fiscal resources. To raise efficiency, there are three key elements: improving the budgetary planning processes and institutional framework; benchmarking measureable outputs; and, finally, raising cost efficiency. Other important and complementary elements are the spending mix and the priorities set by the government.

This paper will review the main components of public expenditure to identify sources of inefficiencies and ways to improve outcomes from government intervention. A first section will highlight challenges ahead, pointing in particular to infrastructure gaps, education quality weaknesses and poor health outcomes. A look at revenue collection will determine the extent to which the government could raise more resources. Next, an examination of budgeting will reveal some aspects that could improve policy formulation and implementation. The paper will then describe the characteristics of decentralisation, which is an essential part of Indonesia's organisation of public services, and the implications for public spending efficiency. Finally, outlays will be scrutinised by main categories: subsidies, infrastructure investment, education, health and the social safety net.

Figure 2. Government effectiveness in selected countries, 2015

Percentile rank

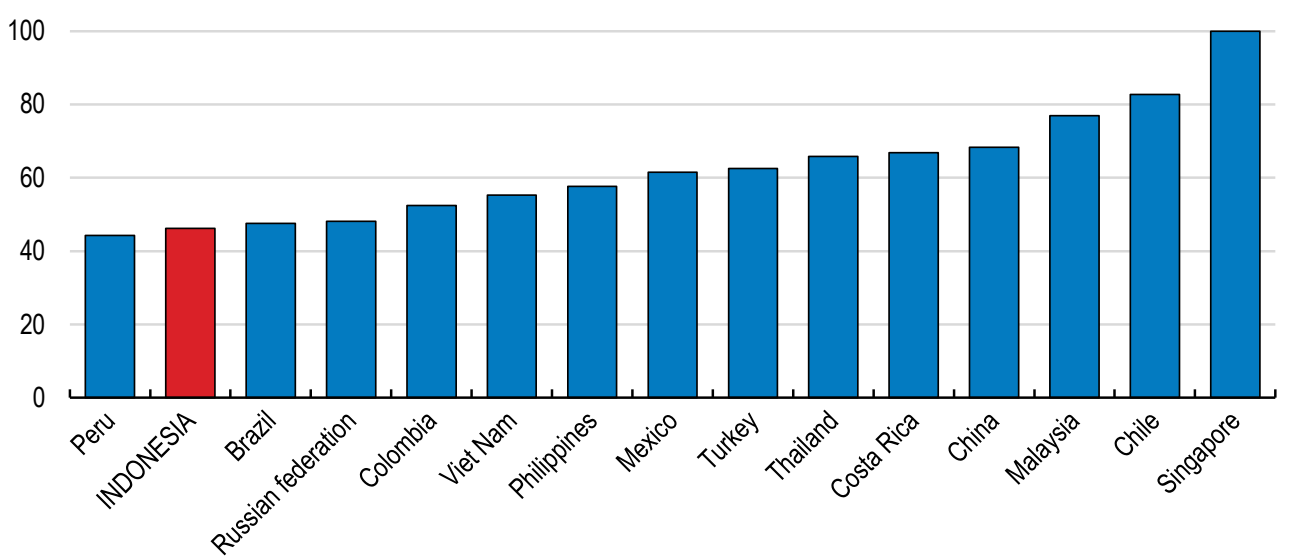

Note: Government effectiveness (percentile rank between 0 and 100) measures perceptions of the quality of public services, the quality of the civil service and the degree of its independence from political pressures, the quality of policy formulation and implementation, and the credibility of the government's commitment to such policies.

Source: World Bank Worldwide Governance Indicators.

\section{Government's role in development: huge improvements, but important gaps remain}

Indonesia has seen huge improvements over the last 50 years across a wide variety of social and economic measures, including an impressive decline in the mortality rate and achievement of comprehensive access to basic education (more below). It is difficult though to disentangle the effects of public spending and simply the impact of economic growth leading to higher well-being for more people. Fournier and Johansson (2016) stress the importance of a well-functioning government in determining its appropriate size and subsequently the right balance between possibly contrary effects on growth and equity. Additionally, besides the delivery of public services aimed directly at improving the welfare of the population, just getting the fiscal framework and spending mix right may itself engender broad-based growth. And of course conversely, having the wrong framework and mix could seriously impede growth by distorting markets and crowding out a more dynamic and innovative private sector. That said, the role 
of public investment is much clearer and points to a positive effect on growth from activities where there are market failures and public-goods externalities. For instance, Égert et al. (2009) demonstrate a positive effect of infrastructure spending beyond the effect on the capital stock (on the broader positive role of public investment, see United Nations (2009)). However, its fruitfulness is dependent on the quality of public investment management which, according to World Bank data from 2010 (Actionable Governance Indicators database), suggests that Indonesia (whose index is at 1.5) is performing poorly in comparison with Brazil (3.1), South Africa (3.5) and Thailand (2.9).

Despite improvements, infrastructure weaknesses still hamper economic development in Indonesia. According to the World Economic Forum (2016), Indonesia's competitiveness (ranked 41st out of 140 countries) is dragged down by the poor quality of its infrastructure (60th). Low electric power consumption per inhabitant results from weak demand and poor access but, given its level compared with similar countries, also highlights a lack of generating capacity, which in turn inhibits capital investment, particularly in mining and manufacturing (Figure 3, Panel A). Besides, despite the gap, electricity production has not increased much in the past decade (Panel B). As mentioned in the 2015 Survey (OECD, 2015a), the dearth of efficient transport infrastructure is also a major issue for Indonesia: overburdened road and rail networks, a lack of airports, inefficient seaports and more generally high logistics costs penalise the economy heavily.

Figure 3. Electricity indicators in selected countries
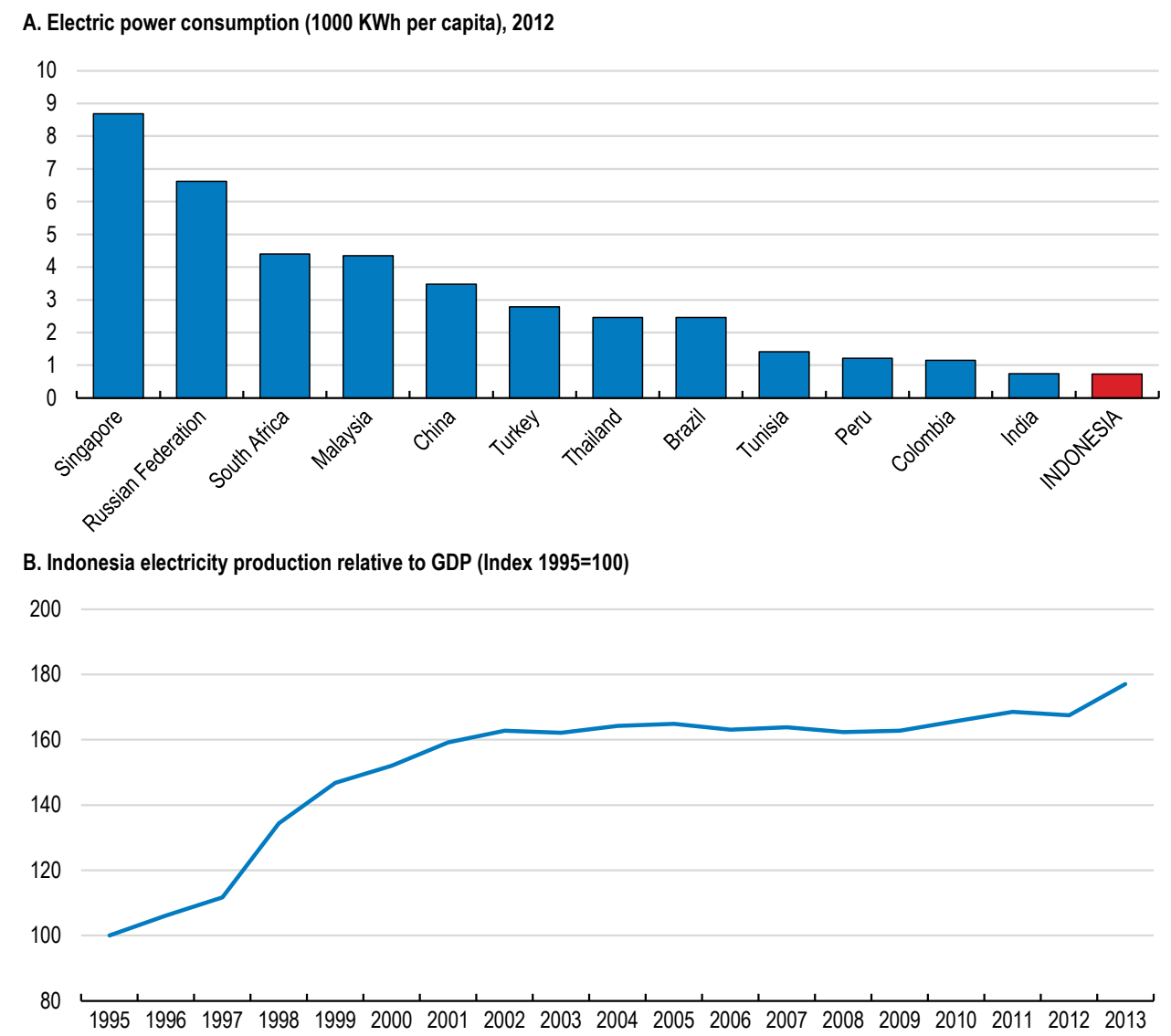

Source: IEA/OECD, Electricity Information, 2015 edition; OECD Economic Outlook database.

The well-being of Indonesians has improved greatly in recent decades. Major successes include primary school, which is now attended by almost all Indonesian children, and enrolment in secondary school that 
has risen steadily from less than $20 \%$ of children in 1970 to over $80 \%$ in 2015 (Figure 4)

Figure 4. Selected indicators on health and education for Indonesia over a long period

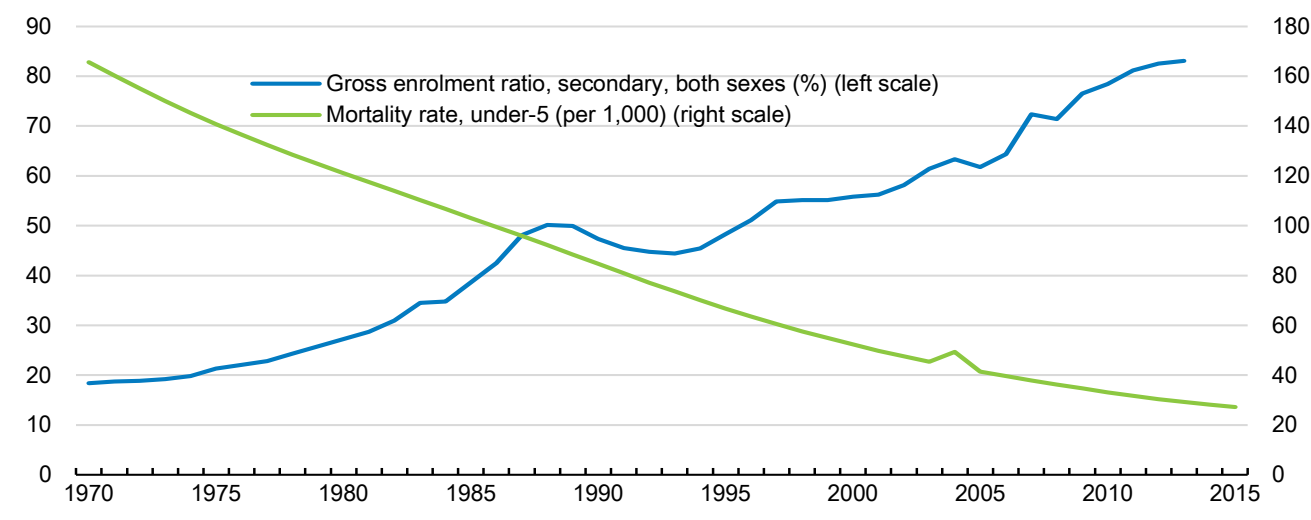

Source: World Bank World Development Indicators.

However, the 2012 OECD PISA (Programme for International Student Assessment) survey, which compares the academic performance of 15 year-olds across the globe, found that Indonesia ranked behind Viet Nam, Thailand, Malaysia and Brazil in basic mathematics, science and reading proficiency (Figure 2.5, Panel A); adult skills as measured by OECD (2016b) also appear weak (Panel B). Despite remarkable progress (like the plunging mortality rate for children under five), Indonesia's health outcomes also tend to underperform: for instance, other countries at similar levels of development usually have a lower infant mortality rate (Figure 2.6). Indeed, the authorities recognise that health is an issue and have increased its central government spending share to 5\% in the 2016 budget for the first time (more below).

Figure 5. Education outcomes by international comparison

A. PISA scores versus GDP per capita, 2012

Sum of reading, mathematics and science scores (PISA)

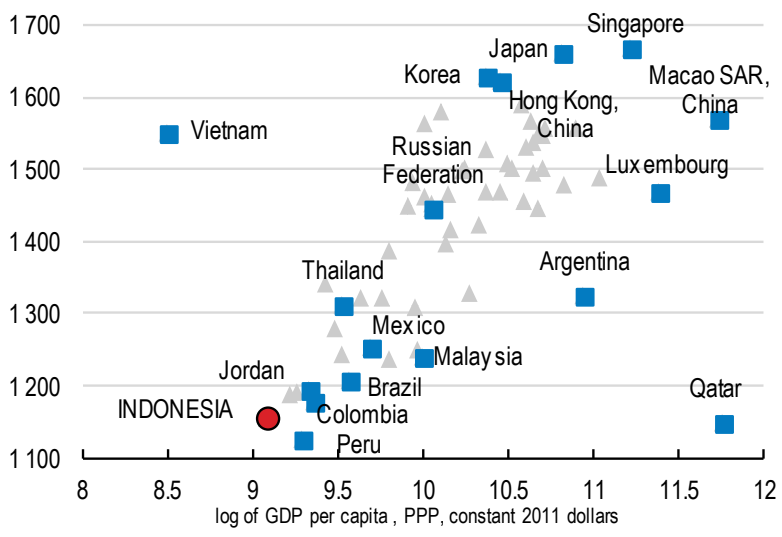

B. PIAAC literacy scores versus GDP per capita, 2015

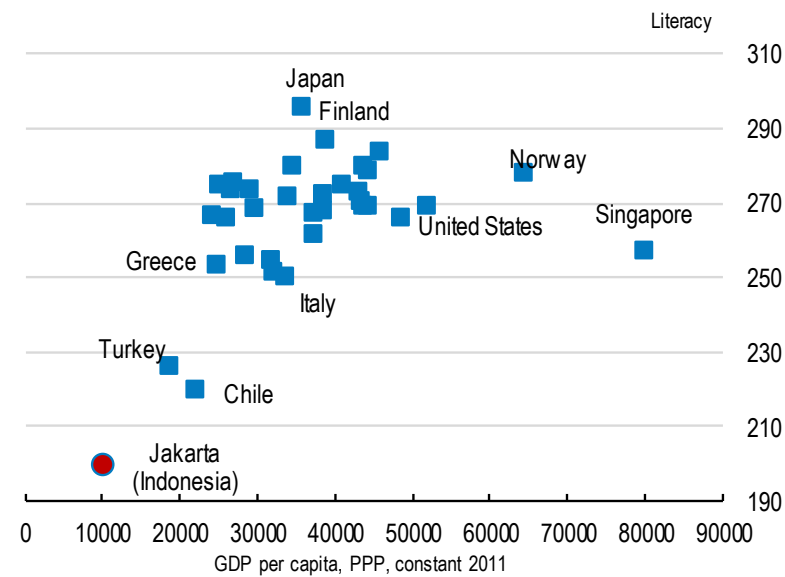

Source: OECD 2012 PISA database; OECD 2015 Survey of Adult Skills (PIAAC) database; World Bank World Development Indicators. 
Figure 6. Child mortality rate and GDP per capita, 2013

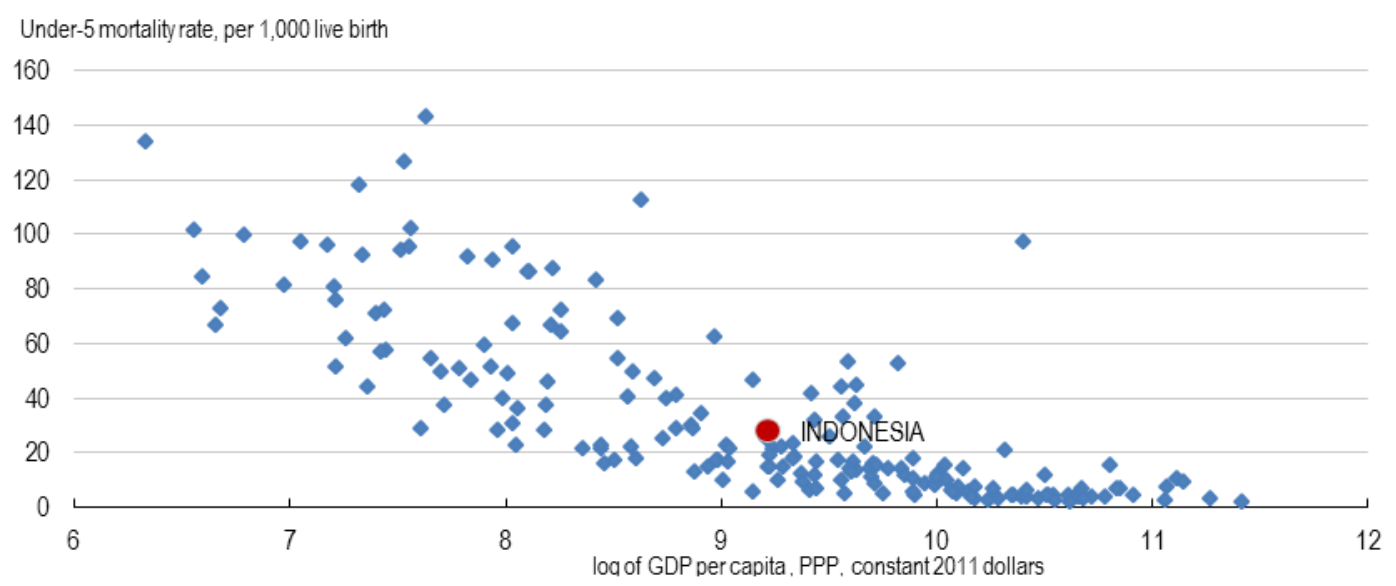

Source: World Bank World Development Indicators.

Further improving public services while maintaining a sound fiscal position will help shape a better future for Indonesians. Major challenges ahead include a population increase of about three million people per year and one of the highest rates of urbanisation (urban population growth averaging $3 \%$ per year for the last 15 years), both of which are set to continue in the medium term. This demographic dividend represents a good opportunity but will also translate into demand for more basic infrastructure, thereby adding to existing gaps, which have become a major concern for private investors. Promoting the development of poorer regions also requires government intervention - regional divergence is a major issue (see Vujanovic, 2017). In addition, the spending mix is not adapted to respond to inequality challenges. Lustig (2015) concludes that among seven middle-income countries, Indonesia's fiscal policy has the smallest redistributive effect. She reports that Indonesia's net indirect taxes are regressive and that total spending on education and on health is not benefiting the poor enough. One of the reasons why expenditure policy is less effective in reducing poverty is that it allocates less to the most effective programmes, such as conditional cash transfers (World Bank, 2015). Indonesia's current and projected social needs are important, which justifies active measures from the state but requires finding the necessary budgetary resources.

\section{Raising revenues will take time}

As described earlier, the share of government expenditures in GDP is low by international standards. Indonesia should consider raising more revenues to fill some of the gaps mentioned above, although addressing spending inefficiencies should come first. Involving the population is crucial: the more people trust in government and in the future, the greater their willingness to contribute. If issues of governance, heavy administrative costs for services provided and lack of coordination among public actors are ignored, there will be no legitimacy for the government to tighten tax compliance. Indeed positive public perception of the government may increase compliance and revenues (OECD, 2013b). According to the Ministry of Finance, 27 million were registered as personal taxpayers in 2015, while the objective for 2016 is about 120 million. Compared with other countries, the share of general government revenues from personal income tax is low (a third in 2014), compensated by higher levies on oil and gas production (13\%) and corporate tax (a third). In addition, actual tax revenues are far below their potential in comparison with peer countries (Figure 7). 
Figure 7. Tax effort versus GDP per capita, 2011

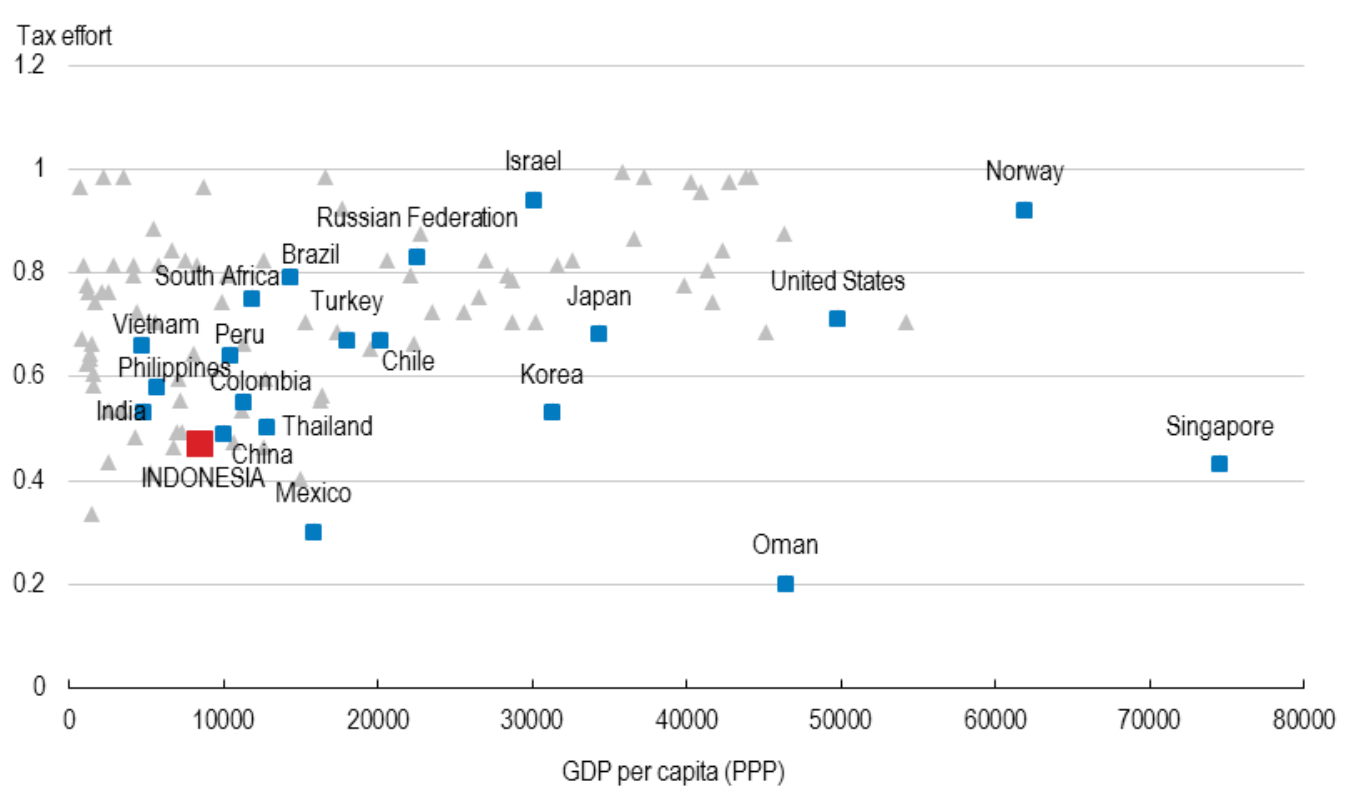

Note: Tax effort is the ratio of actual tax revenues to estimated potential tax revenues computed as a stochastic frontier tax revenue using 113 countries.

Source: R. Fenochietto and C. Pessino (2013), "Understanding Countries' Tax Effort”, IMF Working Paper, WP/13/144; World Bank World Development Indicators.

To improve tax collection and compliance, the government is planning to do more cross-checking of information (including a stronger link between cadastre and owners) and is also developing electronic invoicing for the value-added tax. Making social security contributions and disbursements through the income tax system would also encourage participation. Other countries' experience show that formalisation of small business can work to some extent: Brazil (in 2006) and Mexico (in 2014) have implemented programmes with financial incentives (tax reduction and access to financing) and eased procedures (electronic tools, grouping of tax payments, training) that have reduced the size of the informal sector (currently at about $60 \%$ of the labour force in Indonesia). However, whatever efforts are made, it will take time for the benefits to materialise.

Indonesia joined the agreement for Automatic Exchange of Information under the Common Reporting Standard (OECD, 2013a) in 2015, and the Indonesian authorities intend to start information exchange in 2018. The ultimate goal is to improve the management of cross-border activities through cooperation of tax administrations in today's globalised economy. Indeed emerging economies like Indonesia suffers from revenues losses due to assets hidden abroad. The implementation of the international agreement should spur Indonesia to abandon the use of tax amnesties as done in 1984, 2008 and 2016. Indeed, the recourse to a leniency programme is closely related to government fiscal requirements and taxpayers expectations (Baye et al., 2014). Accordingly, amnesties tend to encourage tax evasion once the grace period is over and boost tax revenues only temporarily. However, the current tax amnesty comes at the right time to offer evaders a way to declare hidden assets before prosecution. Such policy should discourage future attempts to circumvent the tax system through strengthening the tax administration (to manage the flow of data) and a clear statement that this will remain a one-time offer (OECD, 2015f). Other international discussions are underway to facilitate and improve corporate taxation for multinationals under the Base Erosion and Profit Shifting (BEPS) action plan adopted in 2013 by the OECD and G20 countries (OECD, 2015e), which should also benefit Indonesia's tax collection. 
Subnational governments' tax autonomy is very low: only about $10 \%$ of their spending is funded by own revenues. To complete the decentralisation process (more below and in Vujanovic, 2017), Indonesia should gradually set up a closer alignment between spending and revenues at each level of government. That would reinforce accountability and allow a simple approach for regional tax equalisation.

The cost of raising revenues should also be scrutinised. There is a trade-off between having tailored taxes and the administrative cost of maintaining numerous and complicated levies and tax credits. In particular, taxes that yield only a small amount of money should be eliminated or merged into broader ones. Furthermore, in a decentralised context shared taxes imply that a single tax can be managed by several entities (e.g. building tax). Ultimately, the central government should propose a system to facilitate and optimise tax collection at the subnational level. It should also include a centralised taxpayer database that local government could utilise. Officials responsible for audits incur administrative costs; the authorities must be aware of the cost implications of having more controls and consider implementing incentives for officials' to act with integrity.

\section{Government public finance}

Indonesia's fiscal position is sound, but there is not much room for manoeuvre to expand spending without extra revenues. The level of public debt is low compared with other countries (Figure 8), which is both a consequence of the commodity super-cycle and a relatively tight fiscal stance. During the period 2005-14 and especially at the beginning of this decade, government revenues benefited from high commodity prices accompanied by strong economic growth: public debt declined from $80 \%$ of GDP in 2000 to about $27 \%$ in 2015. Additionally, the fiscal framework is traditionally conservative: even during the 1997-98 crisis, when real GDP shrank by about $13 \%$, the budget deficit reached a peak of only $1.5 \%$ of GDP. However, at that time, despite a fall in public spending, government debt increased significantly to bail out the banking sector. Accentuated by a historical tendency for fiscal prudence, that led to the establishment of fiscal rules in 2003, which cap the public deficit and debt at 3\% and 60\% of GDP, respectively. The latter is considered high as debt has negative economic effects as from between $30 \%$ and $50 \%$ of GDP for emerging economies, which are exposed to capital flow reversals (Fall et al., 2015).

Figure 8. Public debt in per cent of GDP in selected countries, $2014^{1}$

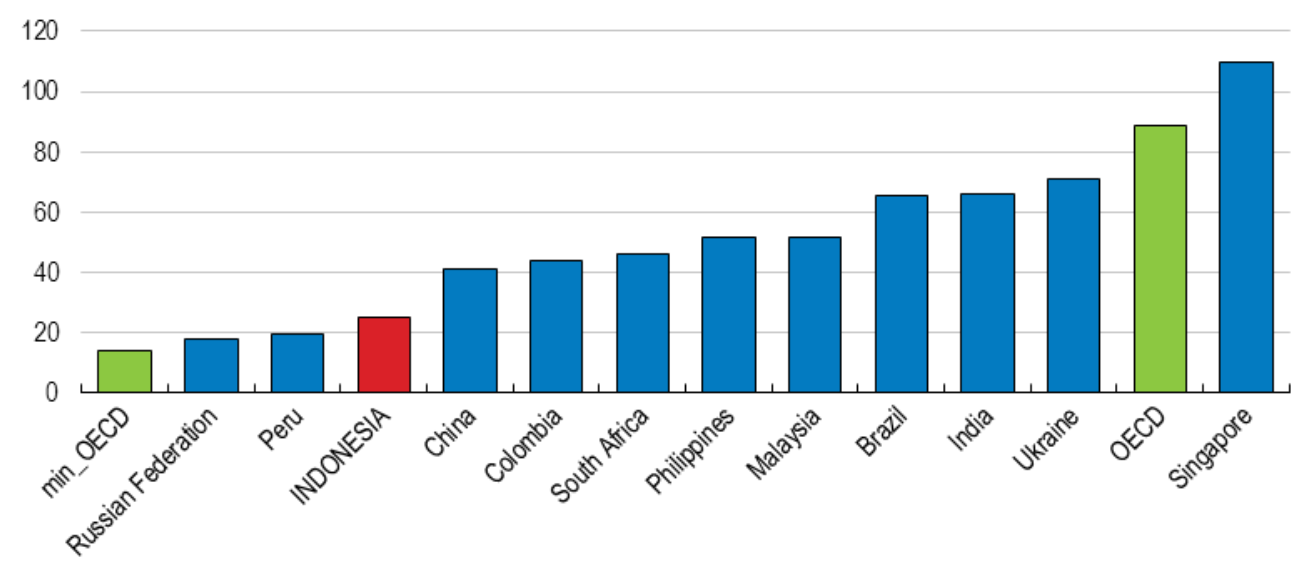

1. 2012 for Malaysia, Peru, Philippines, Singapore; 2013 for Colombia.

Note: Min OECD represents Estonia and OECD the simple average of OECD countries.

Source: OECD Government at a Glance; World Bank World Development Indicators. 


\section{Budget formulation and execution}

A fiscal framework is a collection of budget, tax and other public finance laws, regulations and administrative procedures that governs the use of public funds. It represents the foundations of fiscal policy, and it should promote fiscal discipline and permit stabilisation policies to function. Switzerland, which is often praised in international rankings for the quality of its institutions, shares some common characteristics with Indonesia: they both have a small government relative to the size of the economy, fiscal policy is usually prudent, decentralisation is important, and regional inequality is a concern. In particular, for the way equalisation is organised (Box 1), Indonesia could benefit from adopting the Swiss approach and simplifying the existing complex and ineffective system (see below).

\section{Box 1. Switzerland's fiscal framework}

Switzerland is characterised by a high degree of decentralisation, as is Indonesia. Spending at the federal level is broadly equivalent to the sum of expenditures made by the 2350 municipalities and 26 cantons. General government outlays represented $32.5 \%$ of GDP in 2014 , which is low in comparison with other OECD countries and a share that has remained broadly stable over the past decade. The small size of the public sector goes together with fiscal conservatism to explain the low level of (gross) public debt (45.9\% of GDP in 2015). All three levels of government can raise taxes and duties and issue debt, explaining their large degree of autonomy and the important taxation differences across regions. Consequently, a financial equalisation mechanism with three components has been established (renewed in 2008) whose main objectives are to offset cantonal differences in financial capacity. A first approach goes through resource equalisation based on tax potential: 16 financially weak cantons receive funds from the 10 richest ones (of about $0.8 \%$ of general government expenditures in 2015) and from the central government (1.1\%); after equalisation, the canton's financial resources per inhabitant should be at least $85 \%$ of the national average. Tax potential is based on the comparison of cantonal resources per capita over the last three years (personal income, corporate and wealth tax) and the Swiss average. Additionally, the contribution from the richest cantons should be between two-thirds and $80 \%$ of the one from the central government. A second element of equalisation, cost compensation, which is funded by the central government, takes into account higher costs for the provision of public goods and services for structural reasons in 23 cantons (0.3\%): half of it goes to 10 cantons for socio-economic factors (benefiting mostly urban areas), with 17 cantons receiving the other half to compensate for geographic characteristics. Finally, a temporary cohesion fund lasting 28 years was introduced in 2008 to facilitate the transition from the previous system for 7 cantons $(0.1 \%)$. The system of equalisation is reviewed by the Parliament every four years. The last report in 2014 noted in particular that tax competition across cantons was not adversely affected (Swiss Federal Council, 2014).

In the early 2000s, following an increase of 30 percentage points in public debt as a share of GDP in the preceding decade, Switzerland adopted a debt brake at the federal level. The fiscal rule requires expenditure to be linked to receipts when budgeting. Additional spending will be granted only if secured by other cuts or additional receipts; and a tax reduction must as well be compensated elsewhere. In practice, well-defined exceptions provide some leeway to be able to react to exogenous developments. The exemption clause allows a deficit in extraordinary situations like natural disasters and severe recessions. However, this exceptional expenditure must be made up in subsequent years. Since then, public debt has been trending down, even though subnational governments may have a deficit (many cantons have their own debt brakes, however). To have a balanced budget on average, a two-year medium-term plan defines possible future room for manoeuvre or constraints on fiscal policy. A longer-term report is also written every four years. It examines the implication of demographic trends for public finances.

A series of reforms in 2003-04 aimed at improving public spending efficiency but failed to succeed in some areas. They responded to several criticisms:

- lack of discipline in budget implementation: notably with important off-budget activities and the separation between routine spending under the responsibility of the Ministry of Finance and development spending supervised by the planning agency, Bappenas;

- weak fiscal sustainability (the budgeting system targeted a single year);

- inefficiency in budgeting practices; 
- $\quad$ opacity (e.g., the budget allocations for individual ministries were not publicly available); and

- a lack of accountability.

The budget is now unified, but the previous separation between routine and development expenditures remains in the form of discretionary versus non-discretionary activities - the latter being particularly inflexible as they are mostly renewals of previous budget lines. This comes on top of other rigidities, such as specifying allocation targets for certain sectors, including $20 \%$ of total revenues for education and $5 \%$ for health (law 36/2009) or 10\% of the total transfers to subnational governments to village funds. As explained in Blöndal et al. (2009), in those circumstances, budgeting then simply consists of allocating a fixed amount for a very large sector but without constraints on how to use it. If the target is not respected, it also appears as a failure, although there is no evident link with outcomes. Additionally, the authorities have also made progress towards efficiency-enhancing, performance-based budgeting (Curristine et al., 2007); however, the focus remains on inputs and mainly ignores what is implied for outputs or outcomes. The government has successfully improved the presentational aspect and available information - for example, to associate spending with economic functions - which helps to optimise budget allocations. Some local-level measures like P2D2 (Proyek Pemerintah Daerah dan Desentralisasi), a programme with incentives given to subnational governments to improve accountability and reporting for infrastructure projects (see below), have fully implemented an output-based approach to improve service delivery. Nevertheless, the overwhelming majority of the Indonesian budget still suffers from a lack of assessment and a resulting disconnect between spending and outcomes. For 2017, the central government is planning to adopt a performance-based budget ("money follows the programme") and to reinforce links with medium-term goals.

A medium-term expenditure framework can anchor annual budgeting in a wider context, allowing multiyear planning to take into account future costs and benefits, with forward-looking priorities and collaborative efforts so as to reach consensus among stakeholders. Bappenas is a public agency in charge of planning strategies at all horizons and synchronising the national and subnational levels. A national long-term development plan for the period 2005-25 is divided into four stages each of five years further split into annual budgets.

With the current government, the third five-year-period (2015-19) has been implemented under the label "Nawacita" including priorities on education, rural development, governance, competitiveness and also specific infrastructure targets for 2019. However, according to World Bank (2013a), Indonesia is positioned in the lowest of three stages in terms of medium-term planning, lacks any reconciliation between spending and resources and still focuses on inputs rather than outputs. The coordination role of Bappenas is shared with four coordinating ministries - for political, legal and security affairs; for the economy; for people's welfare; and for maritime and fisheries - and disputes are settled by the President. While decentralisation may have encouraged innovation and more local control, it also creates a need for substantial cooperation among actors, especially with regards to multi-year investment projects affecting different regions. And typically for some public investment, especially when it involves local governments, there is evidence of a lack of cooperation and harmonisation: Hidayat Putra et al. (2015) take the example of transport in the Jakarta Metropolitan Region (JMR), which suffers from a lack of cooperation amongst local governments, the regional agency, the central government and private companies; similar problems arise for Greater Yogyakarta (Holzhacker et al., 2015). It results partly from excessive fragmentation: for JMR, five ministries, three provinces, three District departments in nine Districts, a business association (Organda) and BKSP (Badan Koordinasi Sertifikasi Profesi, a regional development coordinating body) are involved. The latter is supposed to mitigate those issues but in practice has limited authority.

Budget execution should be streamlined and its approval finalised earlier. After the 2003 reform, the role of the parliament has become prominent. Scrutiny and amendments by the parliament are a sign of a vibrant democracy, but because members lack technical expertise, they tend to focus on specific lines of 
the budget to the detriment of the broad thrust of fiscal policy. In particular, after the annual budget is approved (usually by the end of October), sectoral commissions of the Parliament can block disbursements until their concerns have been addressed. For instance, in 2007 about $45 \%$ of total expenditures were delayed (Blöndal et al., 2009). Such delays partly explain struggles to realise the annual target level of expenditures, especially for local governments, which tend to wait for final technical specifications before committing to spending and as a result concentrate their outlays in the latter part of the year. Moreover, these points, as well as a lack of capability by some local governments, leave them little chance to properly plan and implement investment, notably for infrastructure. The budget execution has improved, though, as unspent funds as a share of total revenue declined from 15\% in 2008 to 7\% in 2013 (Patunru and Rahman, 2014). Spending is also somewhat more front-loaded: it was about $10 \%$ higher in January-July 2016 than a year earlier (according to Bank Indonesia), representing about 67\% of the revised 2016 budget.

\section{Governance}

The quality of governance is crucial, and major efforts should be undertaken to address that issue. Bad management, especially prominent in some areas, clearly reinforces inequalities in terms of access to public services and leads to a waste of money when the quality of spending is poor in terms of planning and implementation; it justifies more control and support from the central government until those regional issues are solved. Indonesia's position with respect to the rule of law signals that while the country's legal framework could be improved, the population perceived that it is not applied consistently (Figure 9). The local government performance index (Box 2) gives some indication of the poor quality of governance of the mining sector in some provinces and shows that revenue collection could make headway. The absence of recent improvement (Komisi Pemberantasan Korupsi (KPK), 2016) and the level of non-compliance raise concerns as to the quality of public management in some local governments. There should be more focus on capacity building, notably through training in regions in need, including those that have difficulties in reporting statistics back to the central government or to spend fully their allocation. For example, in 2013 the share of unspent funds was more than 50\% of total revenue in five of East Kalimantan's 14 districts (Patunru and Rahman, 2014).

Figure 9. Rule of law in selected countries, 2015

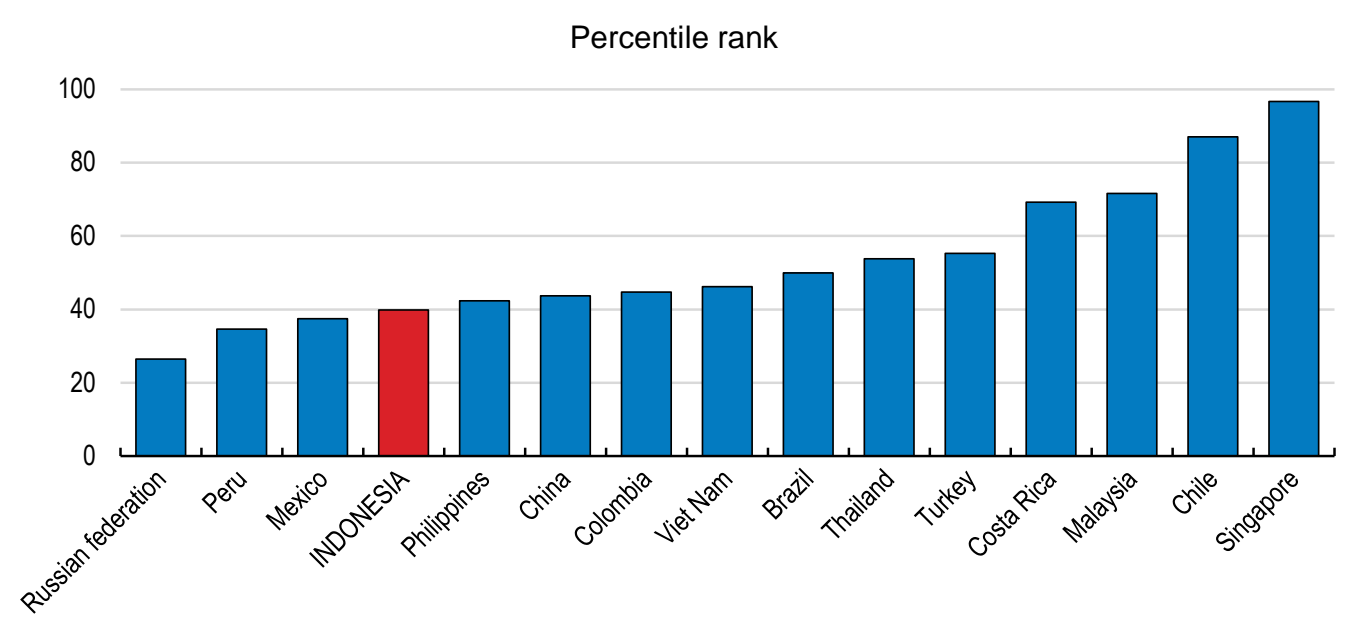

Note: Rule of law captures perceptions of the extent to which agents have confidence in and abide by society's rules, and in particular the quality of contract enforcement, property rights, the police and the courts, as well as the likelihood of crime and violence.

Source: World Bank Worldwide Governance Indicators. 


\section{Box 2. The local government performance index}

The local government performance index is a tool that measures the capacity of a region to follow good practices and to comply with regulations; the survey conducted by KPK (2014) covers mining permits in 12 provinces and highlights that West Kalimantan, South Sulawesi and South Kalimantan are performing badly. More broadly, the study notes in particular that only $60 \%$ of mining licences have received a $\mathrm{CnC}$ (clean and clear) certificate, which certifies the absence of outstanding royalties and other tax debts, the fulfilment of exploration and environmental commitments, a proper delineation of the property and the acquisition of forestry permits. Also, $24 \%$ are not tax registered. And 5.7 million ha of protected and conservation forest were occupied without authorisation. Supervision of production, processing and sales is also weak. Moreover, $90 \%$ of licence owners did not pay certain obligations like land rents. The report also highlighted the problem of illegal mining. Following its release, 1087 licences were recommended to be terminated, and the mechanism to grant licences was revised. An integrated spatial database is also being developed to better monitor land use.

Governance should also improve with the development of digitalisation, as this hastens the circulation of information, reduces errors and improves transparency. Development of e-government is ongoing in Indonesia, with, for instance, the open access of 2015 education budgets of each province, regency and municipality through a website and a mobile application; e-training could also be worthwhile to overcome some of the local government capacity problem. Electronic procurement is also making progress (more below). Those efforts should be pursued together with extending Internet access to a larger share of the population. Indonesia is also a founding member of the Open Government Partnership, which emphasises transparency of government actions, accessibility of government services and information, and the responsiveness of government to new ideas, demands and needs. The recent review (OECD, 2016a) stresses the role of the central government, which should continue spreading open government values across the public sector.

Corruption should be attacked by all available means, as it penalises Indonesians both because of stolen money and misallocation of funds. For many years now Indonesia has ranked badly in international comparison for bribery, though there has been some recent progress (OECD, 2015a). Decentralisation seems to have aggravated the situation (Silitonga et al., 2015); as mentioned in Suryadarma (2012), additional (education) spending in a highly corrupt region has a negligible impact on public services, while it is positive and large for less corrupt regions. The role of KPK (the Indonesian Corruption Eradication Commission) should be strengthened, and concerns regarding its head should not be allowed to paralyse the institution, as happened during 2015; in addition the agency should intervene more at the subnational level. Amounts of fines and penalties should also be raised, as there is a large gap between them and losses for the government budget (Pradiptyo, 2016). Development of statistics should continue as well, because they limit bribery and more broadly facilitate budget allocation. Yet, Indonesia's overall statistical capacity has declined in recent years (Figure 2.10). 
Figure 10. Statistical capacity in selected countries

Composite index between 0 and 100

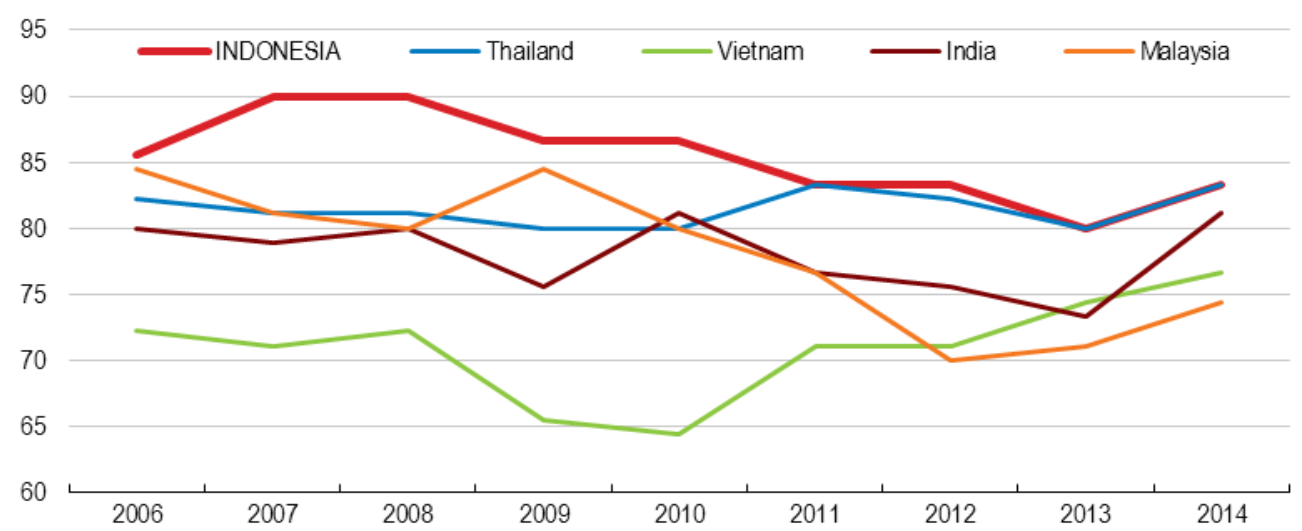

Note: The indicator assesses the capacity of a country's statistical system based on the following areas: methodology; data sources; and periodicity and timeliness.

Source: World Bank World Development Indicators.

Given the critical role of government in economic development and social security, Indonesia's small government makes it all the more important that public expenditure is well targeted and efficient. There is indeed not much room to increase spending in the short term because of the fiscal rule and of the less robust economic situation than hoped for, which forces the government to optimise the current level of expenditures and get the most out of them. It is therefore doubly important to better assess and evaluate all programmes - to check the size of the impact compared to the cost and who mostly benefits - not only when they are envisaged but following implementation as well. That should also include the way local governments spend the funds central government provides and the quality of the overall decentralised governance structure (Vujanovic, 2017).

\section{Enhancing the decentralisation approach}

An important characteristic of Indonesia's government is the prominent role of the subnational level, which was on average over the last decade responsible for about a third of total public expenditures (Figure 11). For 2016, an even bigger share for regional spending (about 40\%) is foreseen, with a growing importance of 'village funds' (Vujanovic, 2017). While subnational governments enjoy a great deal of discretion in terms of their expenditure mix, their revenues come mostly from central government transfers (about 90\%) organised through four main pillars (Table 1):

- DAU (Dana Alokasi Umum, general purpose grant fund) represents the main source of financing (about 60\% in 2014) and is a general and untied block grant. Local governments favour it, as it leaves them with a large degree of freedom in spending. But it is computed using a rather complex formula taking into account the wage bill and a fiscal gap. The latter is based on a difference between needs and capacity and a set of weights that depends on the level of government and on variables of interest, including natural resources, population, surface area and regional socio-economic inequality.

- The specific allocation fund (DAK, Dana Alokasi Khusus) - which became a specific-purpose grant in the 2016 budget - is a targeted grant financing capital expenditures prioritised by central government (including education, health and infrastructure) and mainly depends on local government submissions. 
- $\quad$ Revenue sharing (DBH, Dana Bagi Hasil) is based on a system of percentages (depending on the recipient and the revenue) from tax and non-tax incomes collected by the central government. The amount depends on various internal and external factors: for example, the decline in 2015 is explained mainly by low commodity prices and the domestic economic slowdown.

- The item 'Autonomy and other funds' is mainly devoted to Aceh, Papua and West Papua for rural development.

Figure 11. Central government spending and transfers to the regions

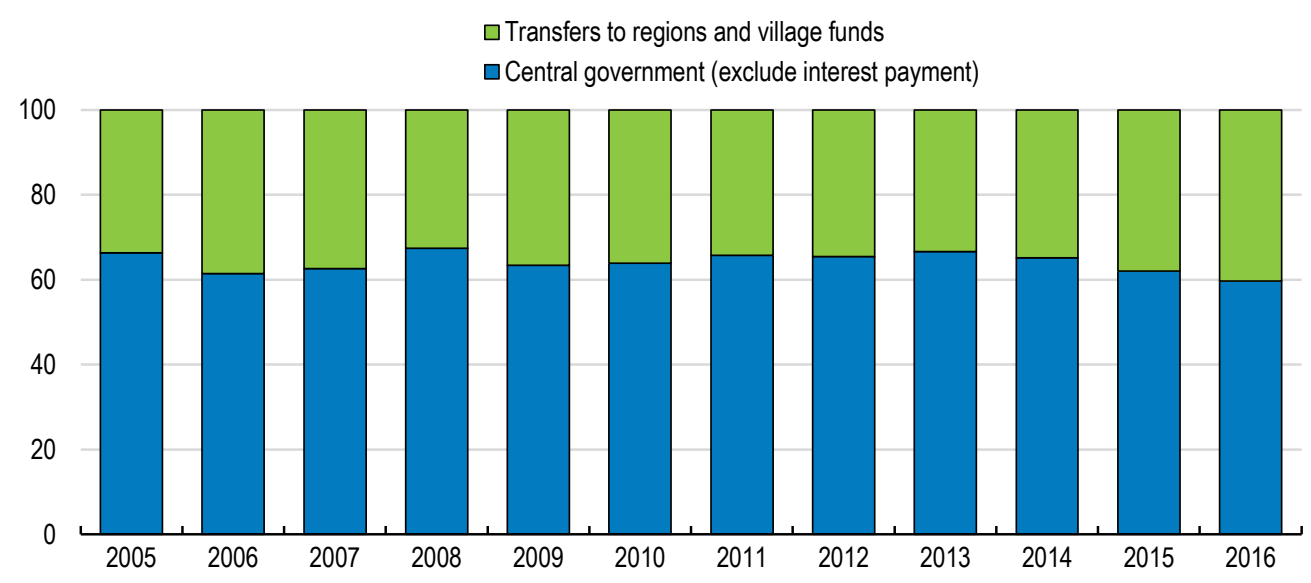

Note: Data refer to the revised budget for 2016.

Source: Ministry of Finance.

Table 1. Breakdown of central government transfers to subnational governments by type

\begin{tabular}{|c|c|c|c|}
\hline & 2014 & 2015 & 2016 \\
\hline \multicolumn{4}{|c|}{$\%$ of total transfers to regions and rural funds: } \\
\hline Revenue Sharing Fund (DBH) & 18.1 & 16.6 & 13.8 \\
\hline General Allocation Fund (DAU) & 59.5 & 53.1 & 50.0 \\
\hline Special Allocation Fund (DAK) & 5.6 & 8.9 & 27.1 \\
\hline Autonomy and other funds & 16.8 & 21.5 & 9.1 \\
\hline \multicolumn{4}{|c|}{$\%$ of general government spending, excluding interest: } \\
\hline Transfers to regions & 34.9 & 36.3 & 40.3 \\
\hline TP/Dekon & 1.1 & 0.9 & 1.6 \\
\hline
\end{tabular}

Note: The data are based on actual data for 2014, on the revised budget for 2015 and on the preliminary budget for 2016. DAK transfers in 2016 include School Operational Assistance (BOS) and additional teachers' allowance fund, previously classified elsewhere. TP/Dekon refers to a deconcentration fund used by line ministries for regional development.

Source: Ministry of Finance.

The mix of subnational government expenditures is distorted by the way central government transfers are determined. In particular, basic services should gain more priority. To that end, a revision of DAU would free some resources by limiting personnel expenditure, which accounts for $40-50 \%$ of regional spending (Figure 12, Panel A). The close link between the wage bill and the amount of the DAU encourages regions to have large numbers of civil servants. In 2014 the share of personnel expenditures in regional spending grew by nearly half to the detriment of capital expenditures. The number of civil servants per capita varies substantially across provinces. For instance, the ratio is much lower in Java even if most central government officials are located there (Panel B). However, dissimilarities with respect to the surface area and the distribution of the population can justify more public employment in some places like West Papua. 
In 2013 the share of personnel and administration in total expenditures varied between $41 \%$ in Kalimantan and 57\% in Java-Bali, and this share increased from 2008 to 2013 in all island groups (by from 2 percentage points for Java-Bali to 10 percentage points in Eastern Indonesia) (Patunru and Rahman, 2014).

Figure 12. Provincial spending breakdown and public employment density

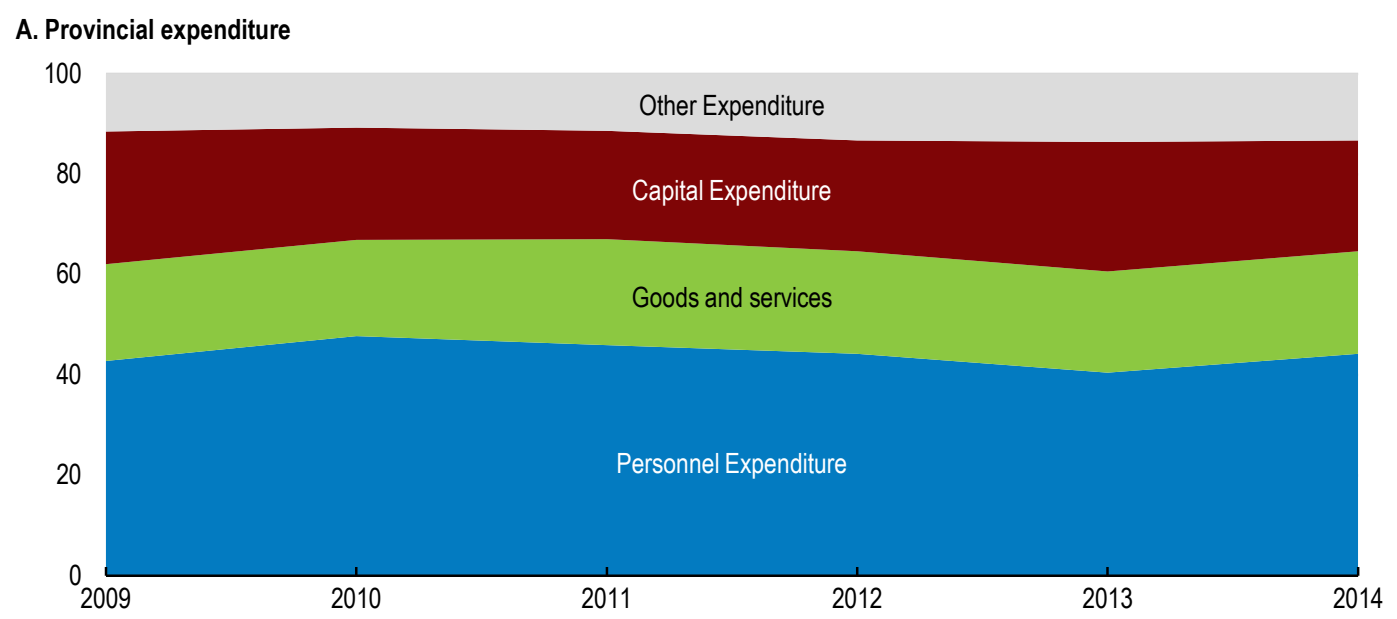

B. Public employment per 1000 people, 2014

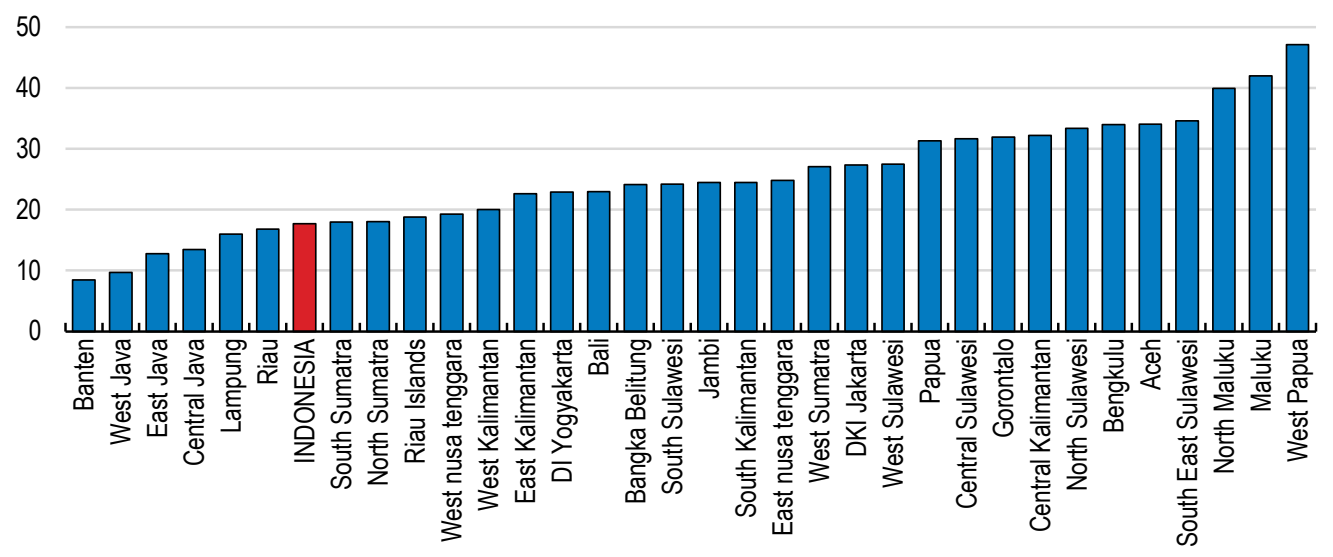

Source: Ministry of Finance; CEIC database.

The central government tries to control personnel spending by limiting local recruitment, but this reduces accountability and the quality of governance at the local level (Shah et al., 2012). The World Bank (2012a) estimates that in 2011 general administration represented about $25 \%$ of subnational spending - while the international standard is about $5 \%$ - and that the increases in education and health-care spending in the previous decade were at the expense of infrastructure. From almost 2 civil servants per 100 residents in 1999, the first years of decentralisation saw a drop to 1.6 in 2004, before increasing again and reaching 1.8 in 2014. The wage bill, driven by local spending, accounted for about $28 \%$ of total general government outlays in 2014, higher than the OECD average (23\%). It is crucial that the capacity of subnational government improves in order to reap the full benefits of decentralisation.

Continued fragmentation could also limit public spending efficiency. According to Shah et al. (2012), DAU's current design induces the creation of new entities to receive more transfers per head. During the period 2010-14, six provinces, 17 districts, 325 sub-districts and 4079 villages were created. Proliferation is an issue that should be tackled, even if this is politically sensitive, because it tends to increase general administration outlays as each local government needs representatives from most ministries and public 
agencies. That should be balanced against a possible improvement in local public services as proximity to the population helps take into account population needs. In addition, Fadliya and McLeod (2010) report that fiscal transfers do not target equalisation sufficiently, leading to differing capacities of local government to provide public services. Differences across governments in size and demographic characteristics can be large, making it inappropriate to treat them all the same way (World Bank, 2012a). Population in the 500-odd regencies and cities varies from 20000 to nearly 4 million people, with about a quarter having fewer than 150000 and $15 \%$ more than 1 million; moreover, some areas are rural, while others are urbanised. This can justify the creation but also the merging of entities when it corresponds to more homogeneity across the same level of government. However, the recent focus on villages - and the fact that it adds a fifth level of administration - is also questionable, as their size is sometimes too small: about a third have a population below 1000 . A key to obtaining better outcomes is to find the right balance between the role and size of subnational governments. A stable set of regional governments would also be desirable because new entities tend to underperform (due to a lack of experience), and new coordination efforts with the rest of the country have to be implemented. Besides, the quality of governance is already very heterogeneous at subnational level. The Ministry of State Apparatus and Bureaucratic Reform has produced a report (Laporan Akuntabilitas Kinerja Instansi Pemerintah, LAKIP) with a grade for each administration for 2015: two provinces (out of 34) have a top ranking (A) while four have one of the worst two grades (C and D); a 2012 report had already identified about 17\% of regencies with a D grade.

Compared to DAU, DAK is to some extent better managed, because it is validated by both local and central governments and also allows grants to be fixed within a medium-term framework while taking into account priorities of different public authorities. Its share has recently increased and needs to continue to do so, especially with regard to the prevalence of infrastructure spending, until the capacity of subnational governments is satisfactory. However, the strengthening should be conditioned on a number of improvements: transparency should be increased and grants tied to defined outputs and agreed unit costs; performance risk should be shifted to local governments for more accountability; provision of incentives should depend on the delivery of sustainable services; evaluations should provide a cost-benefit analysis; and monitoring needs to be enhanced. At the beginning of the current decade the World Bank initiated two programmes: P2D2, which is part of DAK, and WISMP-2 (Water Resources and Irrigation Sector Management Project - Phase II) - promoting investments in water utilities for the poor. Under those projects funding depends on verified and pre-agreed physical outputs. According to Lewis (2014b), targets were achieved in $90 \%$ and $97 \%$ of cases in the first years of execution, respectively; more importantly, outcomes were positively affected compared with a control group, suggesting that Indonesia should further develop such mechanisms, notably for the whole DAK, whose outcomes are more easily verifiable.

Another avenue to explore is the role that incentives and performance should have in shaping local spending, which means properly assessing and evaluating policies. A recurrent criticism of decentralisation in Indonesia is that the sudden huge transfer to local governments did not deliver good value for money (World Bank, 2012a; Lewis, 2014a). This may explain why it lags behind some peers in several aspects (including infrastructure and quality of education). Decentralisation implies greater subsidiarity, which allows local officials to better discern people's needs; it also gives the population more leverage when demanding better services (Martinez-Vazquez and Vaillancourt, 2011). However, a lack of accountability and capability of local institutions may generate weak outcomes; it justifies the use of intergovernmental incentives to encourage improved performance. In Indonesia, the Ministry of Finance has gradually improved its monitoring of service delivery, focusing mostly on infrastructure, education and health care, but so far without a system of rewards/punishment (Lewis et al., 2015), aggravated by a lack of law enforcement in some cases. Units from the central government or from the provincial level should also provide technical assistance to subnational authorities that lack capacity; those units could gather different competencies and professionals to help answer concerns raised at the local level. 
More improvements are needed to avoid fragmentation of transfers and risks of duplication. Fourteen different types of allocations to subnational governments exist in the 2016 budget, of which 10 are part of DAK. On top of transfers to regional authorities, the central government directly intervenes in regions via a programme labelled TP/Dekon, which represented 2.4\% of total expenditures in 2012 before declining to about $1 \frac{1}{2}$ per cent in 2016. This "deconcentration" fund seems to perform better than local intervention, but there are coordination issues with local entities. More broadly, as stressed in Holzhacker et al. (2015), risks of overlapping competencies should be further tackled. To some extent, the numerous transfers together with low own-source revenues (only about 10\%) limit the autonomy of subnational governments, tend to make them fiscally lax and reduce spending efficiency and accountability. In sum, decentralisation, while broadly a success, remains a challenge; part of the problem results from the central government not fully trusting local authorities, which indeed have more room for improved performance.

\section{Improving public procurement}

Improving the public procurement system will limit bribery and corruption, but promoting the principles of fairness, efficiency, effectiveness, accountability, transparency and non-discrimination will also have positive effects on the quality and right-sizing of government projects. The rapid early-2000s decentralisation caused the emergence of different legislation across Indonesia, a divergence which was gradually stopped after Presidential Regulation 80/2003. The later Regulation 54/2010, which followed recommendations by the OECD (OECD, 2007), was a milestone and was amended several times (in Regulations 35/2011, 70/2012, 72/2014 and 04/2015), reflecting the government's will to continue improving it.

The 2010 regulation introduced several novelties. Its scope was extended to include donations and foreign loans. Then, the previously large role of the commitment-making officer was shared into three positions: one with the principal responsibility, the second one overseeing the procurement process and the last one determining the winner of the tender. In addition, the revision applied disclosure requirements to the estimated price. Finally, as of the 2010 regulation electronic procurement for certain goods and services became mandatory, which is a step forward as it improves transparency, competitiveness and efficiency. The adoption of electronic procurement for infrastructure projects should also lead to enhanced quality and facilitate entry from higher-quality contractors (Lewis-Faupel et al., 2016). However, enforcement needs to be stepped up, as only a minority of central and local government procurement budgets follow the 2010 law (Patunru and Rahman, 2014; Nurmandi, 2013); there should be a credible plan to have all central and local government entities use electronic procurement. Additionally, while transparency has improved in terms of online data availability, Trimurni et al. (2015) report in a case study that it is not yet satisfactory. It is crucial that each step of the procedure be transparent.

The quality of procurement depends on civil servants' integrity and training. Having more officials involved as enacted in the 2010 regulation (see above) is welcome, as it brings cross-checking and more human resources; however, individuals need enough expertise to follow the procedure and not allow any circumvention. Data from three Indonesian cities show that the quality of manpower is essential to satisfactory procurement outcomes (Nurmandi and Kim, 2015). In 2007 a national public procurement agency (Lembaga Kebijakan Pengadaan Barang/Jasa Pemerintah, LKKP) was established to develop human resource capacity, devise regulations, and monitor and evaluate the system, but it suffers from a lack of authority. LKKP should also participate in improving awareness of the rules by participants and the general population, including the difference between transparency and disclosure of all information. That should go along with a simplification of the system - complexity is sometimes used to hide information which would limit delay due to a failed process followed by a new round. Finally, procurement is a relatively cost-efficient way to implement certain government priorities: for example, it is reasonably easy to add targets related to sustainable development in tenders (for example, a minimum level of energy 
efficiency and the construction of a waste disposal). Procurement is also used in several OECD countries as a way to promote innovation (Appelt and Galindo-Rueda, 2016).

\section{Streamlining subsidies}

\section{Energy}

As recommended by the OECD in the last Survey (OECD, 2015a), fuel subsidies were progressively reduced in 2013-14 before they were largely scrapped at the beginning of 2015 (Figure 13; Figure 14, Panel A). The cut responded to several imperatives: first, to refocus public expenditures on infrastructure; second, to stop subsidising $\mathrm{CO}_{2}$ emissions; and finally to discredit a measure not well-targeted to fight poverty and inequality ( $40 \%$ of its benefits went to the richest $10 \%$ of the population; see also Coady et al., 2015). Subsidies are usually introduced as a temporary fix to repair a market failure or an injustice; fuel subsidies originated from the 1980s when Indonesia was a net oil exporter. However, they tend to be very difficult to remove in practice. Since the recent reform, a new price mechanism, which allows quarterly changes, was put in place to limit volatility and to equalise the price across the country. The fuel price is then determined by a base market price (based on MOPS, an average of Singapore oil price assessments, and including an allowance for reasonable profit pegged at between 5 and $10 \%$ of the base market price) plus VAT $(10 \%)$ and a motor fuel tax $(5 \%)$. For areas outside Java-Madura-Bali, a premium (2\%) is allowed to take into account higher distribution costs. In 2015 fuel subsidies declined to about 31/4 per cent of public expenditures from around $13 \frac{1}{2}$ per cent in 2014. If world oil prices rebound, the government should allow them to pass through into retail prices, as permitted by the mechanism, and avoid restoring subsidies to shield consumers. Recent experience shows that the managed floating price has been cut quickly when needed, but the upward revision of April 2015 was smaller than expected (Jakarta Post, 2015), leading to retail fuel prices below market prices on average in 2015, according to Pertamina, the state-owned energy firm.

Figure 13. Share of government subsidies to the energy sector

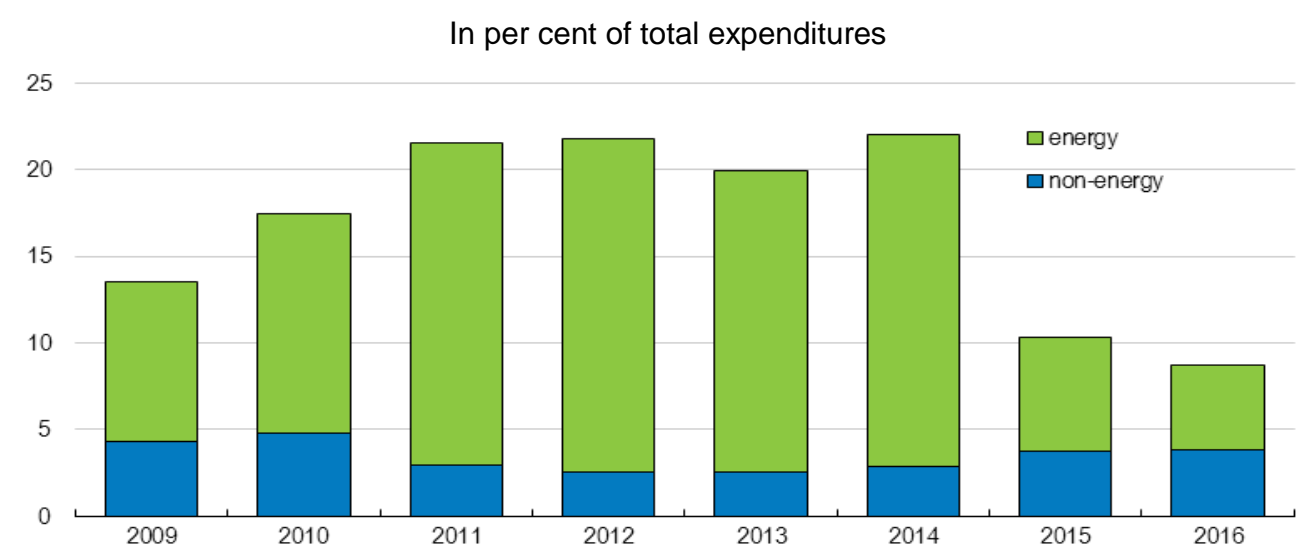

Note: Data refer to the revised budget for 2016.

Source: Ministry of Finance. 
Figure 14. Breakdown of government subsidies

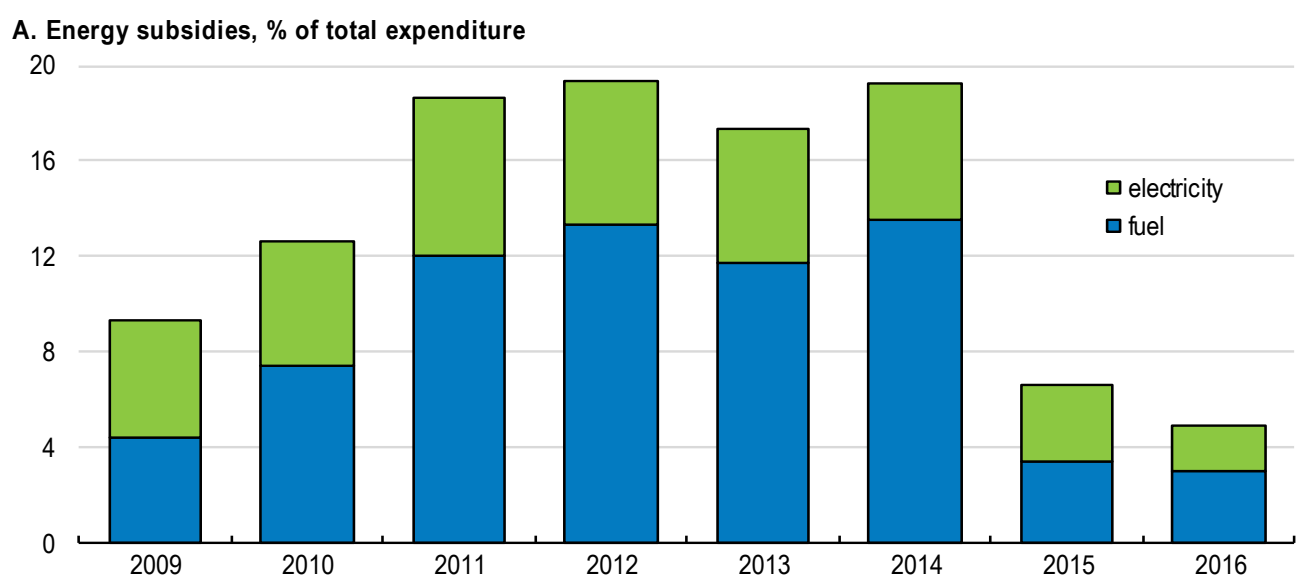

B. Non-energy subsidies, $\%$ of total expenditure

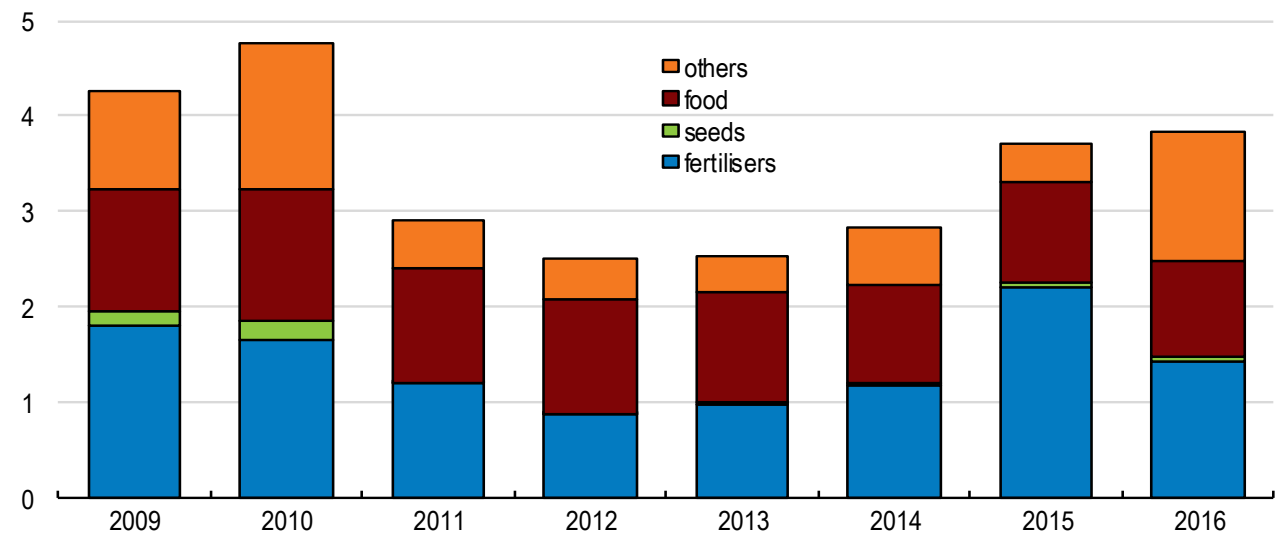

Note: Data refer to the revised budget for 2016.

Source: Ministry of Finance.

Other subsidies still exist for petroleum products. Along with the removal of fuel subsidies, specific fuels (diesel) continue to receive a fixed amount of IDR 1000 per litre (Beaton et al., 2015). In mid-2016, the government halved this to IDR 500 per litre; the gradual removal should continue. In addition, LPG (liquefied petroleum gas) has been promoted since the "Zero Kero Program" launched in 2007. That has pushed the share of LPG in household consumption from 1.5\% in 2005 to $13.5 \%$ in 2013 to the detriment of kerosene, and consequently increased these subsidies from $1.4 \%$ of central government spending in 2010 to $2.8 \%$ in 2014 (Toft et al., 2016). As for fuel, LPG subsidies tend to be highly regressive: on average among seven countries including Indonesia, only $4.5 \%$ of them reached the lowest income quintile a few years ago (Granado et al., 2010). Indonesia should scrap them and use part of the savings to provide the poorest with cash grants to alleviate the extra burden.

Another welcome change is the reform of electricity subsidies (postponed from January to mid-year 2016), which aims to reduce their share in total expenditures from about 33/4 per cent in 2015 to a budgeted (i.e. before the postponement) $13 / 4$ per cent in 2016 . The reform attempts to better target the needy population, as previously some households used multiple connections to limit consumption per unit to become eligible for subsidies. According to data from PT PLN (the state-owned electricity distribution monopoly), in 2015 about 48 million households received those subsidies, while the 2016 budget target is to limit them to the 25 million poorest households. Coordination with TNP2K (Tim Nasional Percepatan Penanggulangan 
Kemiskinan) and its 'unified database' (more details below) alleviates the burden for PT PLN and allows an improved selection of beneficiaries.

\section{Non-energy}

Food security/resilience is a very strong government commitment. It cost nearly $7 \%$ of expenditures in 2015 and more than $6 \%$ of the 2016 preliminary budget (more than health care). The main objectives include efforts to improve the affordability of staple goods for the poor, while maintaining price stability, and to increase domestic production and productivity, thereby moving towards self-sufficiency. The objective of self-sufficiency should be carefully designed and not be achieved at all cost: Dawe (2013) claims that rice production per capita is more dependent on the proportion of well-suited land than yield per hectare. Encouraging production by restricting imports actually discourages consumption via higher domestic prices and should be abandoned. The focus on supply is also sometimes justified by the importance of agriculture for households in rural areas; however, as shown by McCulloch (2008), only a small number of farmers (those with larger farms) benefit from such high prices as the rest of the population consumes more than they produce.

One component of the food resilience policy is agricultural subsidies, which represent at least $3 \%$ of 2015 public expenditures (excluding loan support) and are shared between fertilisers (two-thirds in 2015), food prices (30\%) and seeds (Figure 14, Panel B). Targeting issues are a common risk in this area, especially in a country with weak institutions. In the case of fertilisers, a government report affirms that $30 \%$ of subsidies were misallocated in 2015, with a positive bias for large plantations (Reuters, 2016). Moreover, as mentioned in Armas et al. (2012), in Indonesia such subsidies had a negative effect on farm output while overall public spending on agriculture had a positive impact. Gradually phasing out fertiliser subsidies would free up resources to devote to more cost-efficient programmes, such as irrigation systems, rural infrastructure or research. The promotion of fertilisers also potentially leads to overuse, which could result in soil depletion, weighing on productivity, and in water/land pollution. The government is in the process of developing a database of farmers to address targeting issues of the subsidies.

The second set of food subsidies concerns RASKIN, initially an emergency food security programme implemented during the Asian crisis, which entitles about 15 million households to purchase rice at a cheaper price. The programme faces several challenges: poor quality, missing quantities, the existence of a premium for beneficiaries and insufficient targeting (more details below). Hence, the food security programme is unable to entirely fulfil its objectives and BULOG (a State-Owned Enterprise in charge of food security) should refocus its actions towards managing emergency reserves.

\section{Filling infrastructure gaps in a tight budgetary context}

Infrastructure can promote inclusive productivity-driven growth. It creates jobs, reduces production costs (notably through improvements in transport and connectivity) and expands overall production capacity. This justifies an ambitious programme to fill gaps in its provision. The infrastructure gap for Indonesia has been estimated at over USD 450 billion over 2010-20 (Bhattacharyay et al., 2012), corresponding to approximately $6 \%$ of GDP every year. But budget constraints force choices to be made.

Inefficiencies in public spending (as noted above) do not justify a low rate of investment because in case of a low public capital stock, investment yields higher social returns, including through positive externalities and fiscal multipliers (Berg et al., 2015). In 2015, as recommended by the OECD (OECD, 2015a), the government announced its focus on infrastructure investment, facilitated by the fiscal space created by cutting fuel subsidies. Consequently, infrastructure spending increased from about $9 \%$ of total expenditures in 2014 to $16 \%$ in 2015. This boost was shared between central and local governments along with more recourse to SOEs (Figure 15). The focus on infrastructure is timely and very welcome. However, the public 
sector will not be able to bear the whole cost alone; its aim should be to both facilitate private investment and to be complementary when possible. Moreover, as argued by Ganelli and Tervala (2015), a positive welfare multiplier - the consumption-equivalent change in welfare for a one dollar change in government spending - of public infrastructure investment depends strongly on project selection. International Monetary Fund (IMF) (2015) highlights that, for emerging markets, 27\% of the potential benefits of public investment are lost due to inefficiencies, including weaknesses in management institutions, national and sectoral planning, central-local coordination and multi-year budgeting.

Figure 15. Infrastructure spending

In per cent of total expenditures

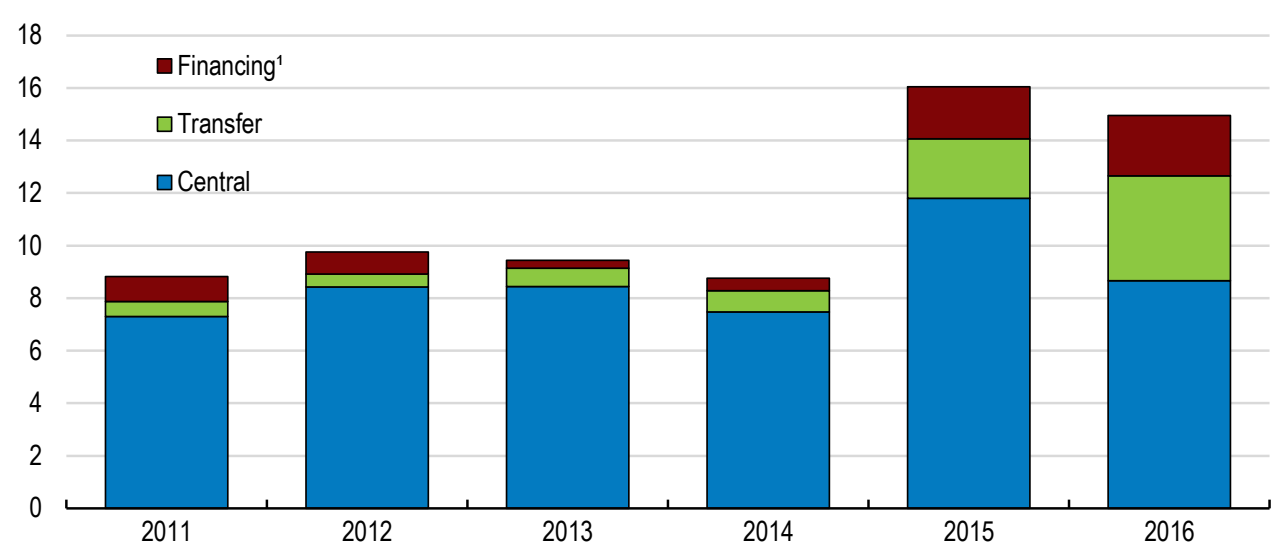

Note: Data are based on the revised budget for 2016. Transfer refers to government transfers to regions that are spent for infrastructure. Central represents the direct infrastructure expenditures of the central government.

1. Mainly state capital injections into SOEs.

Source: Ministry of Finance.

The success of the public sector in providing infrastructure has been disappointing. The authorities have tried to get the private sector on board via Public Private Partnerships (PPP), but with little to show for it, including in comparison with peer countries (Figure 16). Greater private-sector participation would bring additional funds and lessen the burden on public finances but also permit efficiency gains. As mentioned in Indonesia's medium-term framework, Bappenas estimates that less than half of total strategic infrastructure investment needs over 2015-19 can be covered by national and regional budgets. While private firms should be interested in investing because of Indonesia's market potential, this participation needs to be encouraged by a good business climate. This has recently improved but remains unfavourable (Indonesia is ranked $106^{\text {th }}$ in 2016 World Bank Doing Business report). Involving the private sector can extend the number of profitable but unaffordable projects. It can also provide new skills and technologies (especially in the case of foreign direct investment), reduced total costs (for construction and management) and enhanced cost efficiency. Indeed, OECD (2015b) notes that, based on water and energy utilities in 71 countries, a greater degree of private participation is associated with stronger gains in productivity and service quality. A certain number of good practices are necessary though to make sure that PPP projects become successful and avoids potential risks during selection/implementation: establish a strong institutional framework, ground the selection in value for money, and put in place transparency in budgetary and procurement processes (OECD, 2012a); including more specifically for Indonesia a stronger PPP unit, a shortlist of PPP projects and a prominent role for the Ministry of Finance (OECD, 2012b). A mechanism to offer a minimum revenue guarantee would also help increasing the number of PPP projects. 
Figure 16. Public-private partnership capital stock in selected countries, 2013

In percentage of GDP

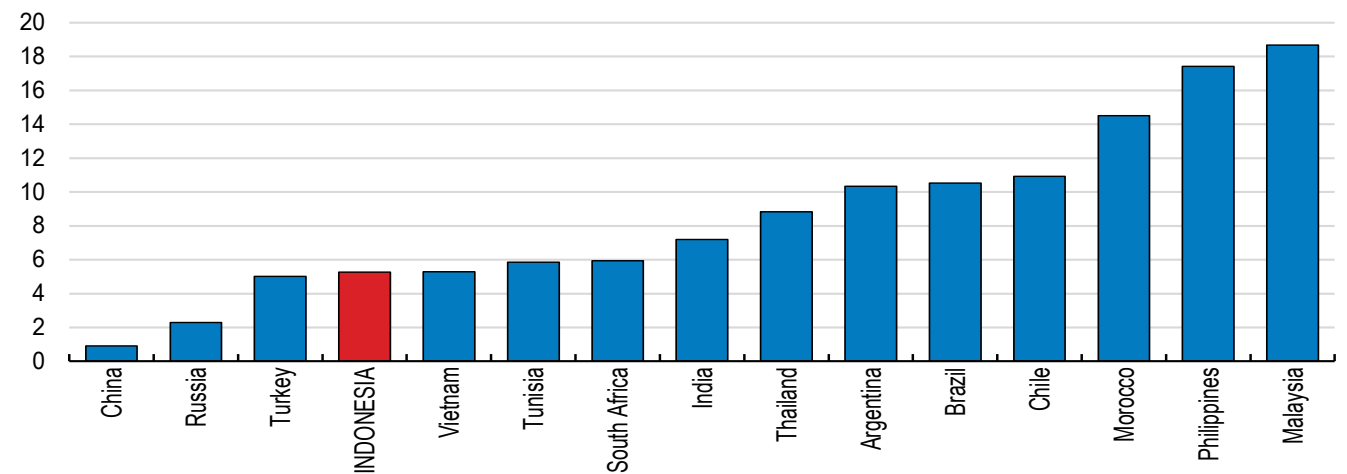

Source: IMF Investment and Capital Stock Dataset, October 2015 version.

In so far as infrastructure provision is concerned, SOEs are a double-edged sword. While they represent an effective means to increase infrastructure investment, they also potentially lead to inefficient use of public funds when they are poorly managed. For the 2015 and 2016 budgets, not only did the government increase its own direct infrastructure investment, but it also encouraged SOEs to do the same, notably by directly injecting capital of 40-50 trillion rupiah (about $2.3 \%$ of government outlays, up from only $0.5 \%$ in 2014) (Figure 15). For Indonesia, the importance of SOEs is sizeable, with 121 enterprises (of which 18 are listed on the Jakarta Stock Exchange) and assets representing more than 40\% of GDP in 2014, almost seven percentage points more than in 2010, but far less than in China (180\%) and Viet Nam (80\%). In terms of capital expenditure, in 2011 Indonesian SOEs spent about 3\% of GDP and consequently about twice as much as the government (according to the Ministry of State-Owned Enterprises). A large and growing number of smaller enterprises are also owned by local authorities: in 2014, 777 (up from 723 in 2011) regionally owned firms' assets were equivalent to about $6 \%$ of GDP. Given their importance, the public money they receive and the potential public guarantee they enjoy, state and regionally owned enterprises should comply with best practices.

The OECD has made several recommendations for sound corporate governance of SOEs (OECD, 2015c), including efficient audits, equitable treatment of shareholders and transparency. Indonesia's Ministry of SOEs releases an annual report with certain key indicators (including net profit, assets by type and dividends paid), but some are not always audited, and the associated feedback report is not available publicly, which makes performance evaluation opaque. Contingent liabilities underlying the participation of the state in those public firms should be fully taken into account, and incentives from the government to have them actively participating in new infrastructure programmes should let them act freely as standard corporate entities. Competence and autonomy of SOE boards of directors should be guaranteed to ensure corporate efficiency and professionalism, and to avoid political interference. The authorities should also be particularly attentive in the particular case of SOEs bidding for PPP projects because of the risk of a conflict of interest.

Financing Indonesia's infrastructure gaps will be a major challenge for the next decade. Public funding has already increased, but there is now limited room for further rises, given the expected slowdown in per capita GDP growth and weakness in other revenue sources, including commodity rents. Apart from enhanced efficiency of government expenditures, expanding tax collection is also possible, but it will take time (see above). Indonesia should also consider further relaxing restrictions to FDI - a negative investment list prevents foreign participation in a number of sectors - which is beneficial to development (OECD, 2002). A recent regulation (82/2015) grants SOEs working on qualified infrastructure projects a 
government guarantee on loans provided by international financial institutions. This is particularly welcome, as it allows them to have cheaper financing for projects that have been validated by the authorities. International development banks can indeed contribute to ease funding programmes: the AIIB (Asian Infrastructure Investment Bank) and NDB (New Development Bank) have recently been created and join the World Bank, ADB (Asian Development Bank), IDB (Islamic Development Bank) and CDB (China Development Bank) in assisting development in Indonesia, with a particular interest in infrastructure. However, the authorities plan to use IIGF (PT Indonesia Infrastructure Guarantee Fund, a SOE partly funded by the State) to provide loan guarantees, which will not be as effective in lowering interest rates as a State guarantee.

Construction costs are high, and maintenance is often neglected. The increase in road spending early this decade, justified by traffic congestion, was partly absorbed by increasing road costs per $\mathrm{km}$, which are comparatively high by international standards, while permanent staff of 11.2 per $100 \mathrm{~km}$ was more than six times higher than foreign norms (World Bank, 2012b). Roads were mostly in good condition at the national level in 2012, but about $25 \%$ of provincial and $40 \%$ of district roads were in bad condition because of a focus of subnational authorities on new development to the detriment of maintenance. Maintenance of existing facilities can pay for itself by reducing future repair costs. To that end, part of road-related user charges, a significant portion of provincial revenues, should be earmarked for maintenance and not considered as general revenues.

Ultimately, planning and realising infrastructure programmes must take into account the whole-of-project cost and should be carefully prepared to avoid delays or cancellation. The government has organised bodies to select, plan and supervise such projects. The inter-ministerial Committee for the Acceleration of Prioritized Infrastructure Provision (KPPIP, Komite Percepatan Penyediaan Infrastruktur Prioritas) is in charge of monitoring a list of 30 priority projects from start to completion and to help find the financing. To that end, it is crucial that all costs are included in the feasibility study, including a proper evaluation of construction expenses and the future maintenance burden, and also of potential environmental damage and risks. For example, the choice to ramp up coal-powered electricity generation in order to meet access targets should take into account COP21 climate change commitments. The financing choice between the public and the private sectors (or a mix of them) should be carefully assessed. There is a usual political preference for mega projects, but, as shown by Flyvbjerg et al. (2003), they tend to be overly complicated and perform poorly.

\section{Strengthening the education system}

Investing in education brings future returns, as it enhances the human capital of the population. It is especially important for Indonesia, where more than $45 \%$ of the population is under 25 . Progress in extending education has been tremendous over the last five decades, but important challenges remain, including raising pupils' academic performance, given that, for example, more than $60 \%$ of Indonesian firms have difficulties in finding suitable employees for professional and managerial positions (World Bank, 2015). Likewise, even in Jakarta, adult skills are weak, as demonstrated by low levels of proficiency in literacy and numeracy (OECD, 2016b). Public education spending is largely determined by a target of $20 \%$ of the total according to a 2002 law, but that share has been budgeted only since 2009 and has never actually been achieved in practise (Figure 17). While Indonesia's public spending on education as a share of the total is in line with international standards, it is low in terms of its share of GDP (Figure 18). Indonesia must now capitalise on its investment and increase efficiency, even if the future decline of the youth cohort should also free up some resources. The problem with such a target is not its level, which highlights the political will for improving education, but that it provides no guidance on how and where to spend it. That justifies putting in place incentives to reach well-defined performance targets including for a better redistribution. In addition, the budget rule is applied jointly to all levels of government, whatever their role, and to any budget revisions, thereby limiting flexibility and predictability. In the end, by 


\section{ECO/WKP(2017)13}

removing inefficiencies, schools might be able to generate improved outcomes and simultaneously decrease total spending by up to $12.5 \%$ (Lewis and Pattinasarany, 2011).

\section{Figure 17. Education spending over time}

In per cent of total expenditures
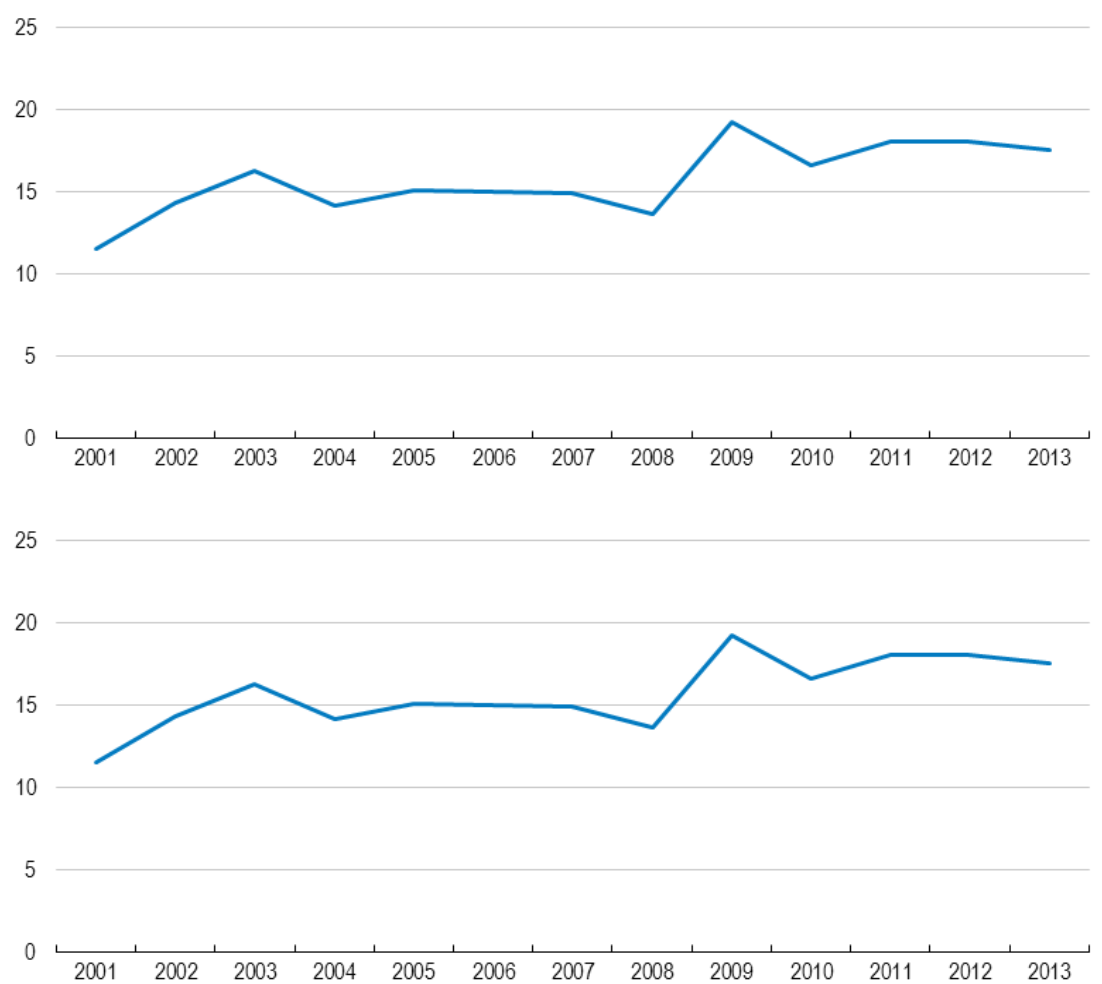

Source: UNESCO Education database. 
Figure 18. Education expenditures in selected countries, 2013 or nearest year
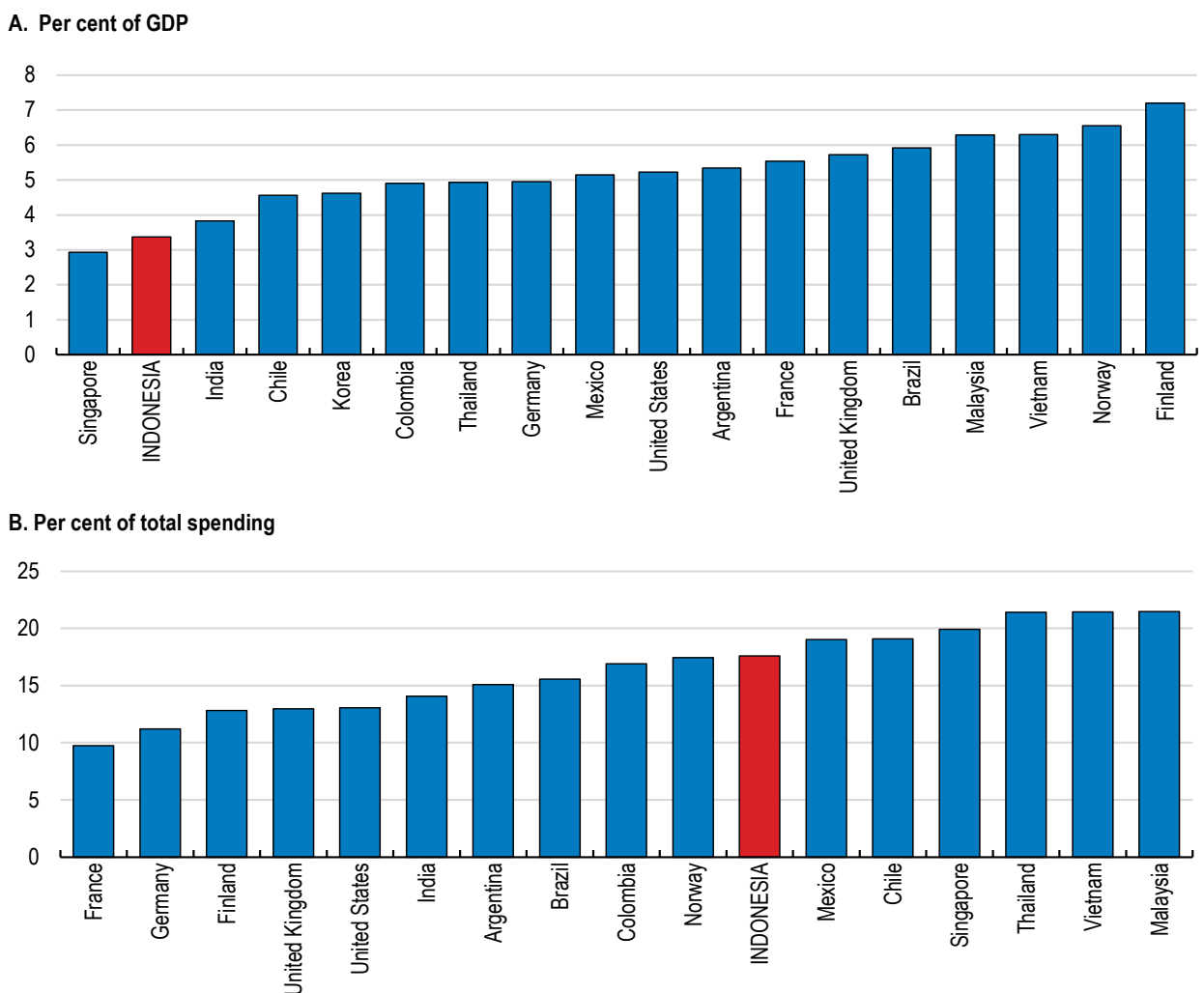

Source: World Bank World Development Indicators.

\section{Shifting spending from primary to secondary school}

Indonesia has long emphasised primary education, and the adult literacy rate has jumped from $67 \%$ in 1980 to nearly $94 \%$ in 2012 . The country is now close to achieving universal basic education after a relatively large increase in investment. In 2005 the government launched a massive school grant programme, the bantuan operasional sekolah (BOS; School Operational Assistance Grant), as a way of injecting funds directly into schools in order to keep children enrolled and give schools some flexibility in managing their own funds. Further assistance is provided by two other cash transfer programmes, Kartu Indonesia Pintar (KIP; Smart Indonesia Card) and program keluarga harapan (PKH; Family Hope Programme). However, despite the apparent success in boosting primary school attendance, there is still significant regional variation in outcomes, and the system could be refined. For example, an evaluation of PKH found that it did not draw more children into the education system nor keep them in primary school, attributing the lack of impact to cash transfers that were too limited and delivered too late to help with parental costs (World Bank, 2012c). Moreover, PKH has been shown to exclude a large proportion of eligible families (GarciaJaramillo and Maranti, 2015). These schemes need to be better administered and more accurately targeted so as to ensure better student attendance and performance, particularly in rural areas. In addition, the separation between state schools (under the management of the Ministry of Education and Culture) and madrasah (Ministry of Religious Affairs) could be made more effective. Indeed, while madrasah are responsible for a significant part of education services, district governments tend to provide insufficient funding to let them generate high-quality outcomes (ACDP, 2013); that should be corrected to avoid inequalities.

While primary school attendance has risen, currently less than one-third of the population has completed secondary education (OECD/Asian Development Bank, 2015). So, the policy focus should now shift 
towards secondary education (including with developing foundational skills in primary schools), which is a key element for providing the labour market with needed competencies for a middle-income country. Resources are still mainly devoted to primary education, much more so than in other countries (Figure 2.19, Panel A). As for spending per student as a per cent of GDP per capita, secondary is even less

Figure 19. Spending by level of education in selected countries, 2013 or nearest year

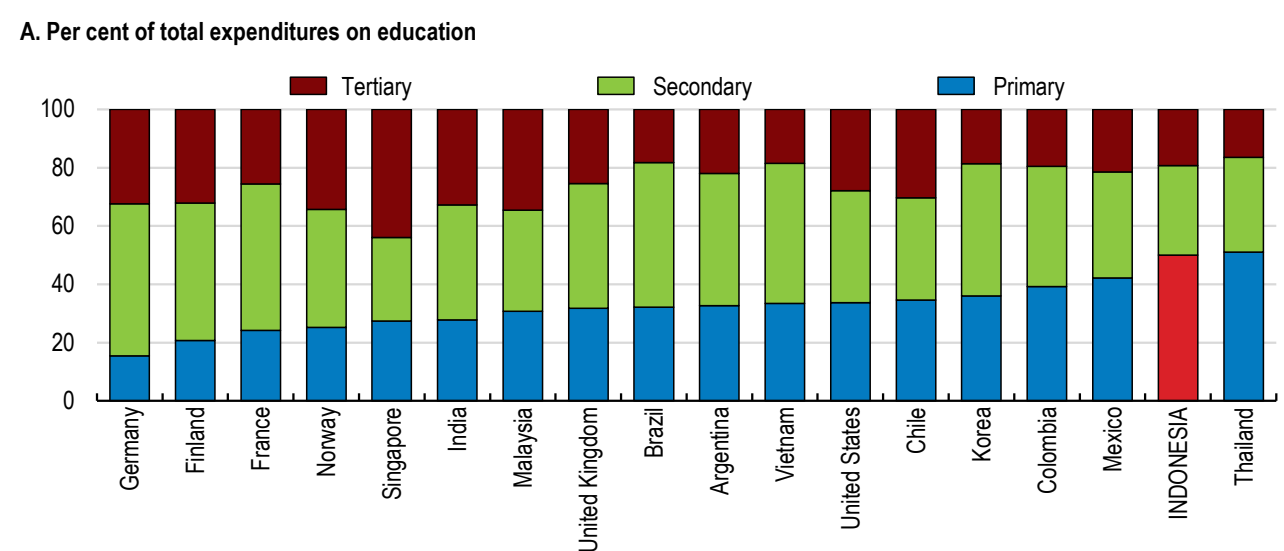

B. Spending per student in per cent of GDP per capita

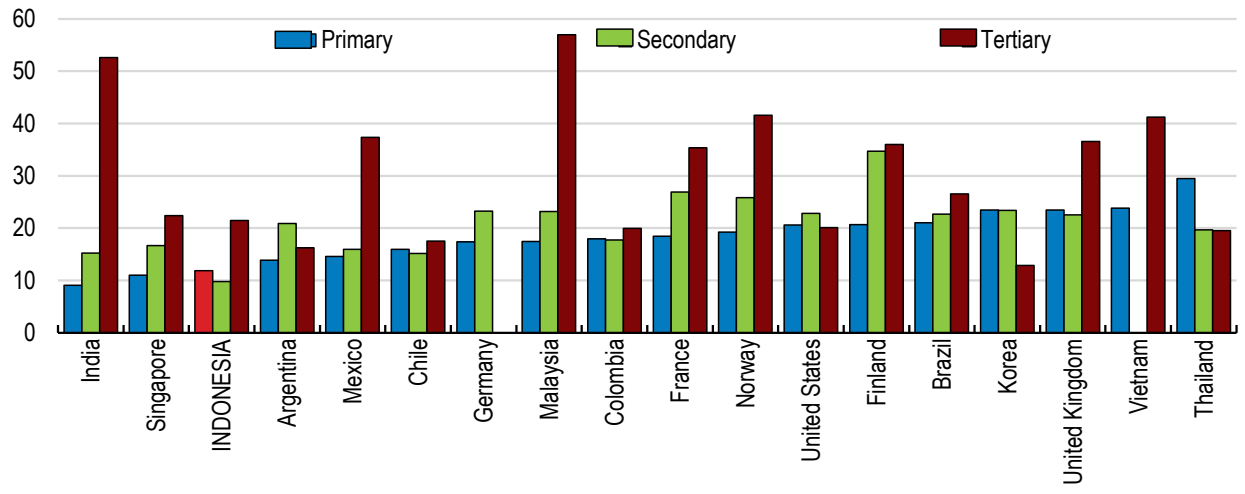

Source: World Bank World Development Indicators.

well-funded than primary education, which is unusual by international standards (Panel B). In particular, access to upper secondary education remains low for the poor. Indeed, enrolment rates for the population in the lowest quintile have improved remarkably for pupils below age 15 but still drop significantly after that (World Bank, 2013b). Efforts to boost participation in tertiary education among disadvantaged groups and regions are warranted, because tertiary education is now mainly dominated by the affluent, who enjoy good schooling and will gain more private benefits following graduation.

\section{The quality of education}

Teaching quality appears low, especially in primary schools (de Ree, 2016). Even though it has improved, teacher absenteeism remains high (10\% in 2013-14), especially in rural areas where physical facilities are poor and supervision sporadic. That leads to higher student absenteeism, classroom hours sometimes below minimum requirements and lower achievement in mathematics (ACDP, 2014). There should be tighter control and better understanding over teachers' activities, in particular to clarify their non-teaching roles: $26 \%$ of absenteeism is justified by official duties, such as attending meetings or training, and teachers take extra jobs to compensate for their low wages (Lewis and Pattinasarany, 2011). While their salaries have improved since then, monitoring recourse to additional extra activities should continue. School 
management needs to improve as well. It is also important to recognise potential virtuous circles. Thus, increased readiness through early childhood education will reduce dropout and repetition rates in primary school, which will subsequently improve secondary and tertiary participation rates. In this regard, the allocation to early childhood education of about $1.2 \%$ of the total schooling budget is far below international averages of 4-5\% (OECD/Asian Development Bank, 2015).

Boosting teacher skills through lifelong training should be considered a priority, including through classroom appraisal and peer learning. The teacher certification programme, set by the 2005 Teacher Law, aims to ensure a minimum level of qualifications by 2015 to be assured either by a diploma or a training course. Teachers who obtain certification then receive a professional allowance that doubles their salaries. The share of certified teachers increased to $63 \%$ in 2013, compared with $23 \%$ in 2005 . In addition, teachers' educational qualifications improved, and the share with a second job declined steadily (Chang et al., 2014). However, students taught by certified teachers have no better learning outcomes than those with non-certified teachers, demonstrating that certification alone, and the doubling of income that went with it, had not generally improved teacher quality. It increased the wage bill though, potentially crowding out other interventions to improve quality: in 2013, nearly $13 \%$ of the education budget went to the professional allowance (OECD, 2015a; World Bank, 2013b). Teacher pay should be based to a greater extent on skills as described in the Competency Standards for Teachers (Ministerial Decree 35, 2010), which uses 14 measures to assess teaching performance.

\section{Personnel spending}

Most of the increase to reach the $20 \%$ spending target has been concentrated in staff compensation. Over the past decade the number of teachers in all except madrasah schools rose by 51\% (Suharti, 2013). As explained above and given that education is managed mainly by districts, there is a tendency to allocate more to personnel expenditures so as to receive more central government transfers. Recruiting new teachers is easy to do as long as the required level of teacher qualification is low. According to World Bank (2013b), two-thirds of the additional resources used to respect the budget rule went for teacher salaries and certification; moreover, the increased number of teachers, especially at the primary level, was due mainly to additional contract teachers, and a trend to convert them into civil servants could put further pressure on the wage bill. The pupil-teacher ratio is already quite low (16.1 in primary and 15.4 in secondary schools for 2013) and shows some significant regional heterogeneity (Figure 2.20). Eventually, with the help of better data availability, recruitment could be made more efficient to hire teachers only when there is an evident need. 
Figure 20. Pupil-teacher ratios in selected countries

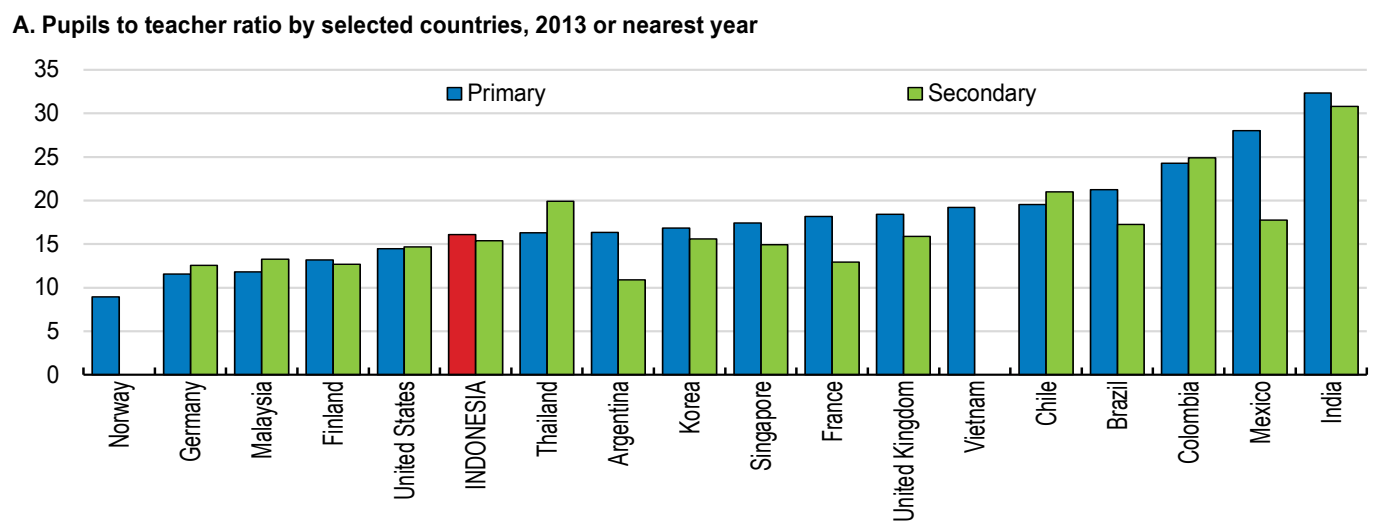

B. Primary and secondary by province, 2014

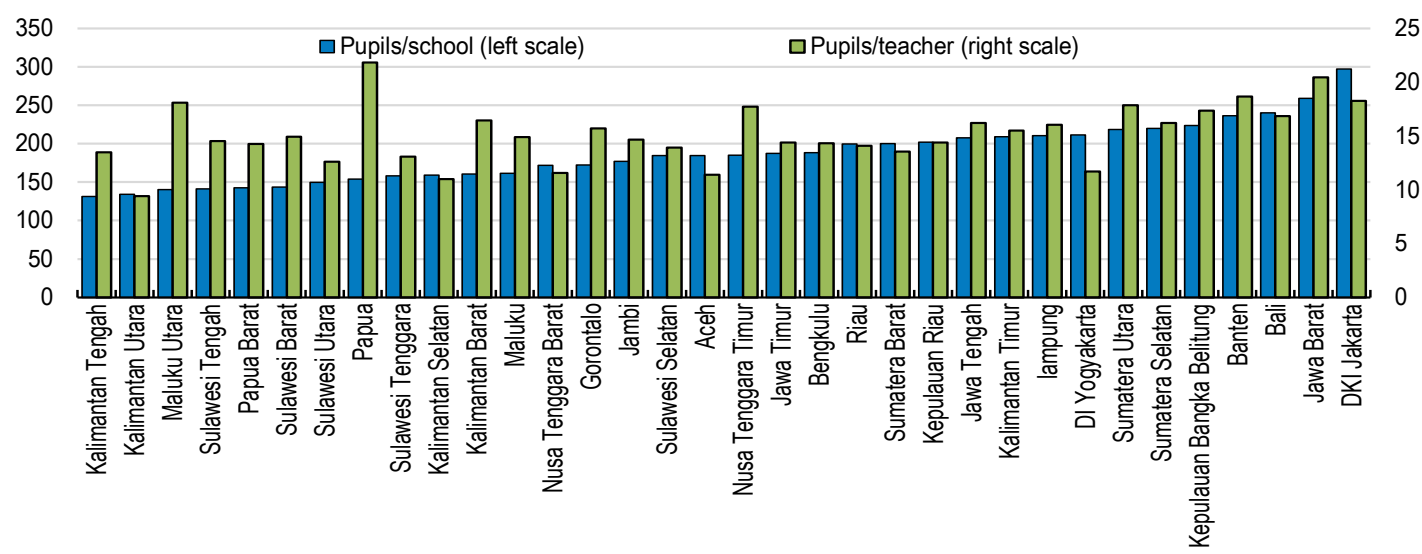

Source: World Bank World Development Indicators; Statistics Indonesia.

\section{Schools}

The education system in Indonesia is characterised by the existence of a multitude of small schools to ensure universal access across the far reaches of the archipelago but also because some grants are provided for each individual school: even aggregating to the province level, average school size ranges from 130 to 300 pupils (Panel B). Teachers are attracted to remote locations by virtue of allowances that can triple their salaries. So, while rural schools are not generally understaffed, staffing classes of ten pupils or fewer with a qualified teacher per class is inefficient (OECD/Asian Development Bank, 2015). When small schools cannot be merged, a more efficient use of teachers should be promoted to restrain pressures on staff compensation, including with multi-grade teaching. Those techniques can encourage more flexible learning, the use of groups and less hierarchy (Blum and Diwan, 2007). They are used in many developed nations (World Bank, 2010). The use of incentives for schools should also be promoted to develop good practices and improve performance. Distance learning (including massive open online courses) is another option that should be considered. It can be much cheaper than traditional teaching, as a course can be taught to students in different locations at the same time including for remote areas. However, it also requires broader access to the Internet and to IT equipment as well as specific teacher skills.

\section{Private sector}

The private sector plays an active role, especially in secondary and tertiary education. While only $7 \%$ of primary schools are private, the share increases to $56 \%$ and $67 \%$ for lower and upper secondary schools, 
respectively (OECD/Asian Development Bank, 2015). The government has committed to achieving universal participation in upper secondary education, extending the period of compulsory education from 9 to 12 years. Achieving that legitimate goal will imply considerable budgetary outlays, justifying diversified funding sources but may also necessitate careful trade-offs and concrete efforts towards more efficiency in education spending. Regarding early childhood education, the bulk of recent growth has been for the forprofit sector accessed by parents who can afford to pay, while approximately 15 million children younger than six were not attending any early child development programme in 2012 (OECD/Asian Development Bank, 2015). Private-sector development should be accompanied by substantial aid for those in need. Likewise, for tertiary education, the current system is inequitable, as most poorer students have to pay to attend private institutions, while those from more affluent backgrounds attend superior establishments at lower cost.

\section{Expanding health care}

Health outcomes have improved enormously over recent decades from low levels, notably in terms of increased life expectancy and reduced infant and under-5 mortality rates. Other indicators draw a less sanguine picture, with for instance the comparatively high maternal mortality ratio at 126 per 100000 live births (Figure 21). Indonesia targets to decrease it to 70 by 2030 under the UN Sustainable Development Goals. Similarly, the infant mortality rate (at 22.8 per 1000 live birth) is high, with the poorest quintile having a three times higher rate than the richest. Health spending remains low by international standards both in terms of total public outlays and as a share of GDP (Figure 22); it has also remained relatively stable since 2010. However, McGuire (2006) shows that, in a cross section of developing countries, public health expenditures are not correlated with decreased infant mortality, but better access to health care is. That suggests that just spending more is not enough to tackle health issues. In the same vein, eliminating inefficiencies in OECD countries' health-care systems could raise life expectancy by an average of about two years (Joumard et al., 2010). Indonesia - with a small health-care budget - is moderately efficient by international comparison but could possibly gain nearly three years of health-adjusted life expectancy by improving the use of current per capita health expenditures (OECD, 2015d).

Figure 21. Maternal mortality ratio in selected countries, 2015

Per 100000 live births

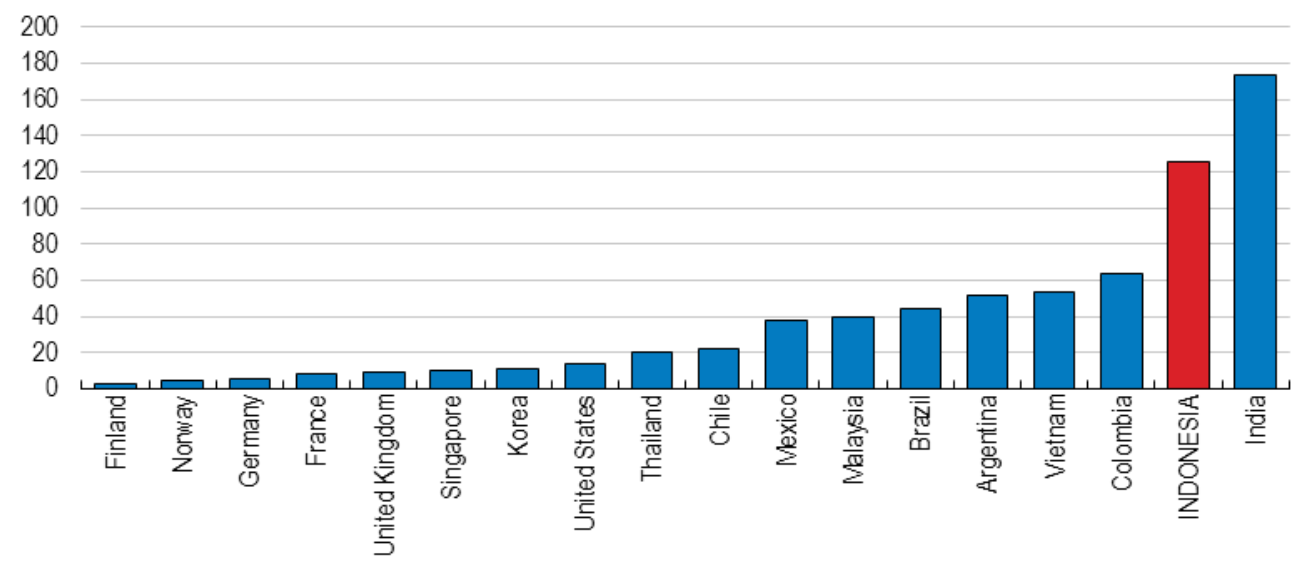

Source: World Bank World Development Indicators. 
Figure 22. Health spending in selected countries, 2014
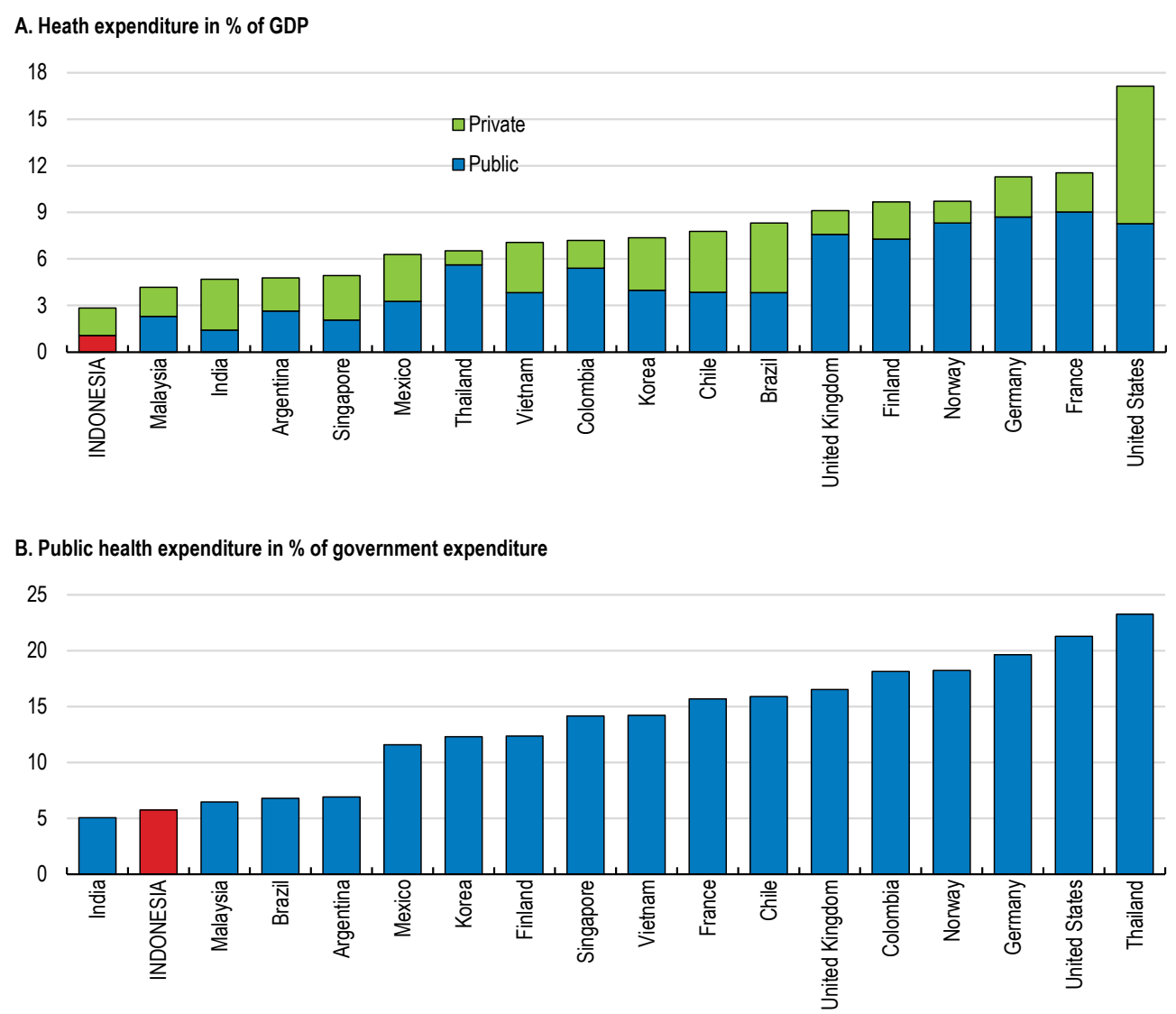

Source: World Bank World Development Indicators.

One of the principal recent initiatives regarding health care is the on-going implementation of universal health-care coverage (UHC), for which Indonesia was ranked poorly in 2009 (Wagstaff et al., 2015). The initial law providing UHC was voted in 2004, but the actual rollout started only in 2014 and is targeted to be finalised by 2019. In January 2014 various public insurance schemes were unified in a single agency (BPJS Kesehatan) tasked with the implementation of the National Health Insurance Program (JKN) aiming at providing health coverage for all. Initially, the programme covered about 120 million existing users of previous schemes - about half of the population - of which some 86 million ex-members of Jamkesmas (a government programme targeted at the poor); the rest consists mainly of civil servants. Having a single actor was an important step toward comprehensive coverage. Nevertheless, the financing of such an ambitious package is still unclear, which raises concerns as to UHC's sustainability (Economist Intelligence Unit, 2015; Hidayat, 2015). The additional amount required could be $2 \%$ of GDP by 2020 (Guerard et al., 2011), but on top of UHC, government expenditures will also increase with economic development. This will trigger higher demand and supply for health services and lower out-of-pocket private disbursements. In 2015, the deficit of BPJS Kesehatan was IDR 4 trillion (around USD 300 million) for 162 million users and is forecast to reach nearly IDR 10 trillion in 2016, while the covered population could reach 186 million (Indonesia Investments, 2016).

To have a sustainable UHC system, the government needs to adjust premiums to reflect costs and make sure that coverage increases equally across population layers. Health-care financing is ensured by premiums paid by the government for the poorest, while the rest of the population is divided into three classes according to their income. To limit the rising deficit, Presidential Regulation 19/2016 recently 
implemented a $20 \%$ rise in premiums for second-class and state-supported participants, and more than $30 \%$ for those in the first class (the richest), while the third-class was untouched. However, while mandatory coverage seems low for workers in the formal sector, because they typically postpone their shift to the new system until the end of the transition period. Additionally, the fixed amount informal workers pay to register with JKN seems too low: the ratio of claims to contributions exceeded $600 \%$ in 2014, whereas it is about $80 \%$ in the formal sector (Ministry of Finance, 2015). Moreover, only about 9 million informal employees were listed with JKN in 2014, while they represent about $60 \%$ of the work force, which suggests that the more they participate, the less sustainable the current framework is likely to prove. On the other hand, offering health coverage to informal workers is vital to avoid health inequality. Fraud is also an issue. It is reported at $24 \%$ for health insurance claims (Global Business Guide, 2013). Another avenue to explore is cutting unit costs (for which Indonesian data are difficult to get). which are estimated to be relatively high (Rokx et al., 2009).

The current and expected increase in health-care services (notably due to UHC implementation) will have to be concurrent with investment in infrastructure and training greater numbers of medical staff. As discussed above, Indonesia suffers from infrastructure gaps, including in the health-care sector. For example, the number of beds per capita is extremely low by international standards, while population growth is still buoyant (Figure 23, Panel A). As UHC is being implemented, demand will increase, putting rising pressure on existing facilities. In Jakarta and East Java hospital bed occupancy rates are already above 100\% (Economist Intelligence Unit, 2015). This justifies devoting a significant portion of infrastructure investment to health, especially in Java where most of the population lives. The expected gap for the country though is huge: even if 15000 hospital beds will be added by 2017 (EY, 2015), there is a need for 500 000. The paucity of physicians per head (Panel B), even more severe in rural areas, should also be targeted, not only to confront the expected increase in health-care demand but to also partly catch up with peers. Foreign doctors are prevented from practicing, which is also damaging, given the existing shortage; the opening of the ASEAN Economic Community at the end of 2015 lifted the barriers inside the zone, but entry is still restricted by the need to pass a test. Ultimately, the finalisation of UHC and associated increased facilities is potentially a major risk for future public expenditure sustainability.

The tradition for the private sector to provide health-care services should be reinvigorated to help fill the gap in the context of public governance of health care. The share of private spending went up to $71 \%$ in 2005 before gradually falling to $62 \%$ in 2014 . As usually observed in developing countries, the importance of the private sector is mostly driven by out-of-pocket disbursements, which represent about $75 \%$ of private spending. However, $62 \%$ of the 2200 hospitals are private, and $60 \%$ of outpatient visits occur at private facilities (Marzoeki et al., 2014). While full UHC will increase the public share, there are prospects for the private sector to expand, given the growing middle class and relatively high profit margins (EY, 2015). However, it is important to prevent the public sector providing only reduced services for the poor and near-poor in a two-tier system. To that end, private hospitals should be encouraged to subscribe to JKN. Yet, in 2013 a pilot system led to financial losses for several private hospitals, which, despite an increase in reimbursement rates in 2014, remain reluctant to participate (Economist Intelligence Unit, 2015).

Investment to combat specific weaknesses in health outcomes (including infant malnutrition) could have important second-round benefits. In Indonesia, nearly $30 \%$ of children under five are stunted according to the national measure; even if that share has declined from $37.2 \%$ in 2013, it remains a concern and is higher than the global average of $28.5 \%$ (Shrimpton and Rokx, 2013). Damage done by malnutrition is seen throughout one's life course in reduced productivity and an increased risk of developing diseases when older. Future economic losses can be potentially large: indeed, Hoddinott et al. (2013) estimate that amongst 17 particularly affected countries the benefit-cost ratio associated with implementing nutritional policies supporting the poor is the highest in Indonesia: a dollar invested in reducing stunting is estimated 
to generate USD 48 in economic returns. That also highlights the importance of assisting people in need and limiting inequality for more than humanitarian reasons.

Figure 23. Health service indicators in selected countries, 2012 or nearest year

Per 1000 people

\section{A. Number of hospital beds}

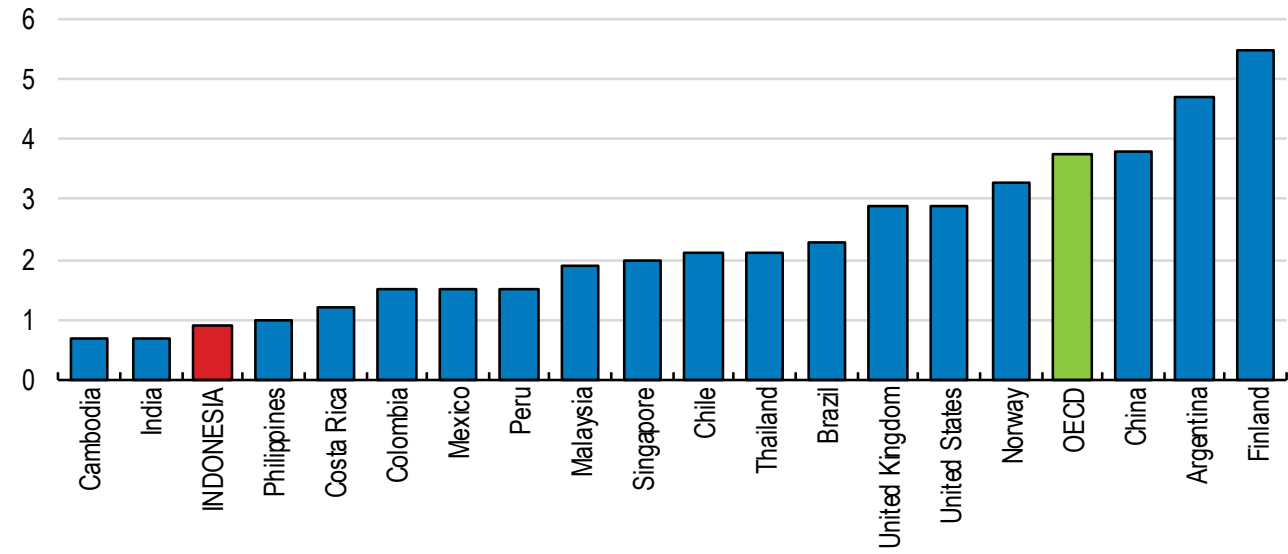

B. Number of physicians

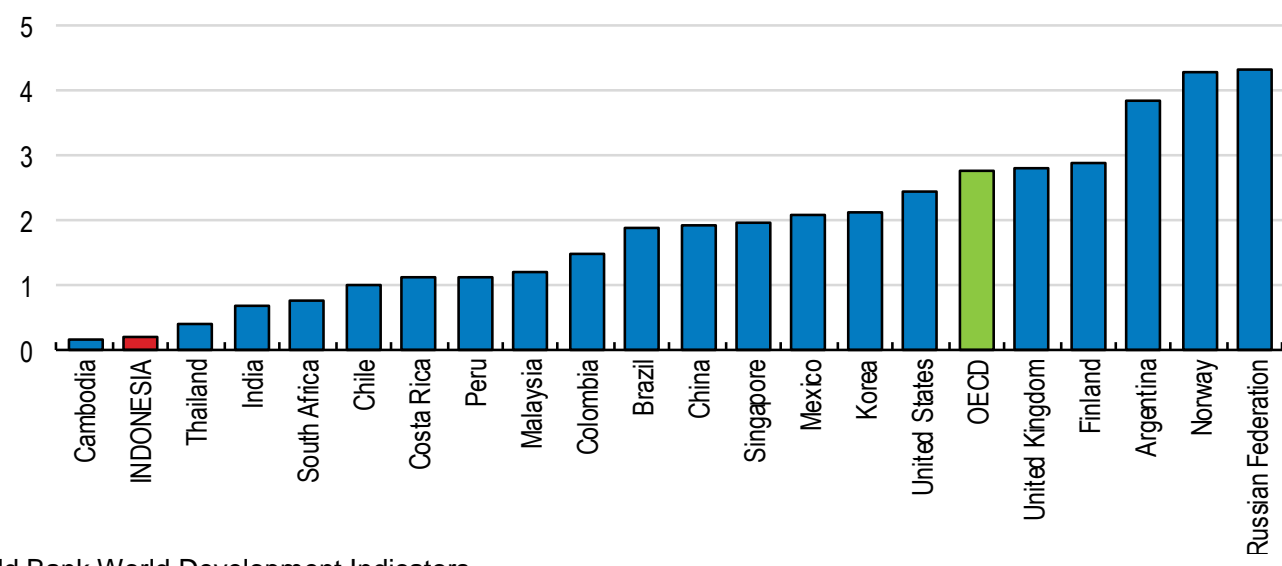

Source: World Bank World Development Indicators.

\section{Managing risks underlying the pension system}

Coverage of the Indonesian pension system is currently relatively low. In 2014 , less than $15 \%$ of the labour force subscribed to the newly-formed BPJS Ketenagakerjaan. This is a public agency formed in 2014 to consolidate the previously fragmented system into a single national scheme to cover the private and public sectors, as well as self-employed and informal-sector workers. The system offers inflation-adjusted defined-benefit pensions based on contributions. The level of contributions is currently low but is planned to reach $8 \%$ of worker salaries. The retirement age will also increase from 56 to 65 over the next three decades. The set of reforms is welcome, but there are financial risks for the government if the system is not fully funded as intended, which justifies close supervision. With a rapid demographic transition in Indonesia, ageing should also be anticipated as population above 65 , currently at about $6 \%$ of total population, is expected to rise to $24 \%$ by 2040 . Eventually, the system would benefit from coordination between the health and employment insurance schemes to remove the necessity for employers to liaise with two agencies for social security contributions. 


\section{Optimising the social safety net}

As described in the last Survey (OECD, 2015a), Indonesia's poverty rate has fallen sharply, yet is still too high (Figure 24). The national poverty rate, defined as the population share below the poverty line (about USD 25 per month), stood at slightly above $11 \%$ in 2015 - over the official target range of $9-10 \%$. The government has to put in place policies that encourage private-sector participation in the economy and to provide basic public goods, such as water, sanitation, health and education, to enhance the well-being of the poor.

Figure 24. Poverty rate in selected countries, 2014 or nearest year

Poverty headcount ratio at $\$ 3.10$ a day (2011 PPP), in per cent of the population

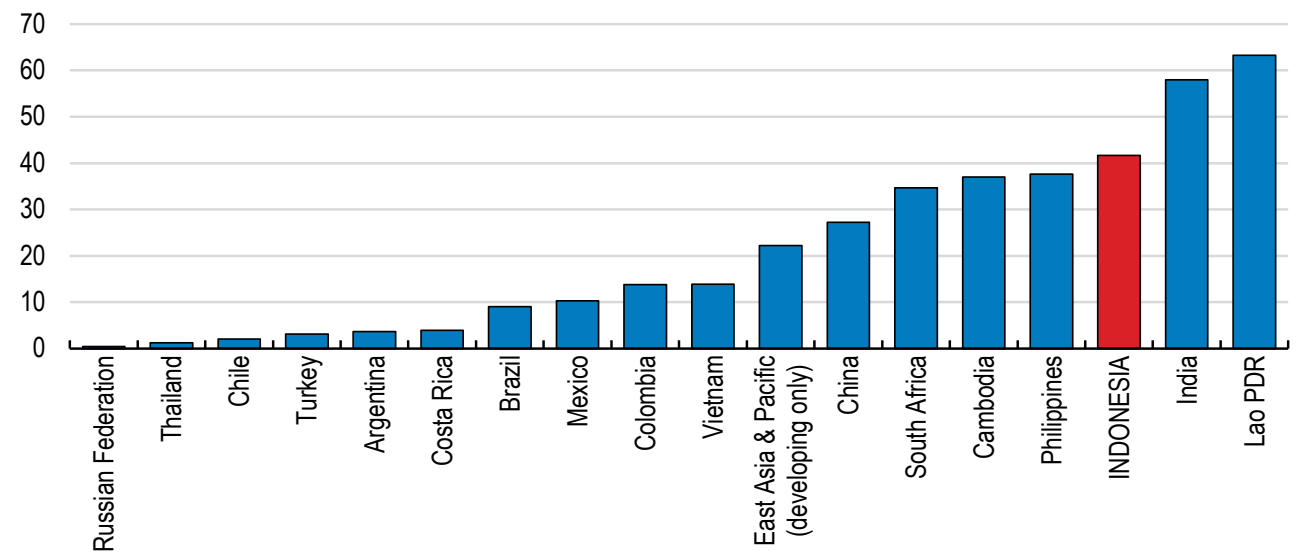

Source: World Bank World Development Indicators.

Current levels of public social assistance are low. With less than 1\% of GDP allocated to social assistance, Indonesia spends only a fraction of what other large, middle-income countries spend (Figure 25). The authorities must not neglect any part of the population. While UHC should be an active

Figure 25. Public expenditures on social assistance in selected countries, 2012 or nearest year

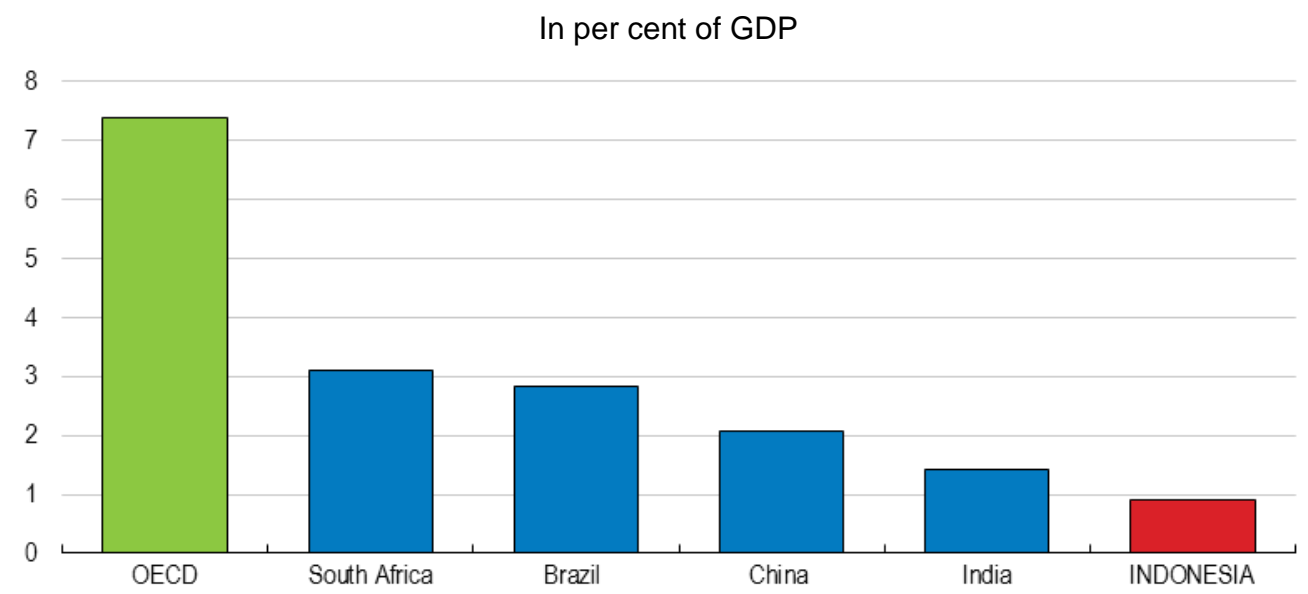

Note: Public social expenditure excluding health and old-age spending.

Source: OECD Social Expenditure database. 
element of redistribution together with in-kind education support, the government should be ready to allocate additional resources to poverty-reducing social assistance, including by better use of existing programmes.

To compensate for high retail rice prices (highest amongst Asian emerging economies) and to help the poorest, RASKIN - the largest Indonesian social assistance programme, with a budget over USD 1.5 billion - theoretically provides $15 \mathrm{~kg}$ per month to the poorest $30 \%$ of the population at one-fifth of the market price. The National Logistics Agency (BULOG) is responsible for purchasing rice from producers and managing quantities through import restrictions and then provides that rice to local governments who take charge of its distribution. But in practice eligible households receive only about one-third of the intended subsidy because they receive smaller quantities at a higher price (Banerjee et al., 2015). Rice distribution is problematic because of local monopolies and a lack of transparency; pilot programmes testing contracting out the last step in the chain are intended to reduce prices and enhance quality. The introduction of social protection cards in 2013 (KPS), subsequently replaced by KKS (family welfare cards), to verify RASKIN eligibility is a positive step. The government also envisages transforming the programme into food assistance through 2017-2019.

A unified database (UDB) of social, economic and demographic information for poor and near-poor households used for several social assistance programmes will help optimise social spending. A 2009 survey showed that only $30 \%$ of the poor received benefits from the government (TNP2K, 2015). In 2012, the National Team for the Acceleration of Poverty Reduction (TNP2K) started the UDB and is currently managing a database (PPLS14) of around 25 million households (96 million people) corresponding to the four lowest income deciles of the population. It is used to provide social assistance through major programmes including RASKIN, BOS (non-personnel funding to elementary and secondary education), KUR (credit for business), PKH (Family Hope Program, given to the $8 \%$ poorest families) and electricity subsidies. Besides, further streamlining of concurrent registries should be envisaged through a single ID number system (as in India), which would notably ease UDB management and updates. Efforts should be concentrated on better identification together with regular evaluation to continue improving programmes as for example done in Mexico with the distribution of food vouchers (CONEVAL, 2015).

Even if small in relation to total expenditures, social assistance programmes are fragmented. In 2014 and 2015, the government launched three different cards based on UDB: KKS (cash ad hoc transfers), KIP (targeting twelve years of universal education) and KIS (to pay JKN premiums). A welcome improvement is that grants through KKS can either be directly transferred to deposit accounts or withdrawn at a cash machine with a SIM card. The use of a single card with different capabilities, apart from simplifying use for beneficiaries, would further limit management costs. Even though expanding conditional grants is recommended as they improve efficiency, in 2014 BSM (a scholarship for poor students; see OECD, 2015a for more details) began to be replaced by KIP. This was a step backward, since this financial support is granted to all families with children below 12 including when they have dropped out of school, thereby wasting an opportunity to nudge families in the right direction. Indonesia should promote conditional cash transfers, as they are effective in reducing poverty as in Brazil or in South Africa, where about $69 \%$ of all cash transfers go to the four poorest deciles (World Bank, 2014). In that regards, the extension in 2016 of $\mathrm{PKH}$ to disabled and old-age people under certain conditions is welcome.

\section{Recommendations to improve the efficiency and allocation of public spending}

\section{Reforming budget formulation and execution}

- Move the budget process towards an output-based approach by improving evaluation of future and existing programmes and reinforcing links with medium-term objectives. Add more flexibility in spending, and abandon budget targeting at too broad a level. Streamline the role of sectoral parliamentary commissions to have the final budget entirely approved at the end of the previous year. 
- Continue the fight against corruption by all means. Improve reporting and statistics to enhance transparency and accountability. Increase the use of electronic procurement and the transparency of public tenders.

\section{Making decentralisation work better}

- Improve coordination between central and local governments but also among regional authorities. Clarify the role of each level of government taking into account the trade-off between proximity, cost and efficiency. Take those considerations into account for the creation of new entities. Weed out overlapping competencies, where possible.

- Revise the system of transfers from central to subnational governments to remove the link with payroll. Further decrease the share of the general block grant in favour of the specific allocation fund.

- Bolster incentives by linking the amount of central government transfers to outcomes realised by subnational authorities. Central government units should provide technical assistance to their local counterparts with capacity issues.

- Avoid fragmentation of transfers, and increase the share of own-source revenues at subnational levels to improve accountability and enhance incentives to grow the local economy.

\section{Improving the allocation and efficiency of expenditures}

- Eliminate diesel and LPG subsidies to ensure better environmental performance. Phase out fertiliser subsidies in favour of the development of irrigation systems, rural infrastructure and research, and direct cash support for the poorest farmers.

- Replace RASKIN with food vouchers for the poorest. Liberalise imports to reduce food prices.

- Continue prioritising infrastructure investment, and reinforce cooperation with the private sector by promoting further PPPs.

- Earmark road user fees for maintenance when possible.

- Allow different levels of government to have different education spending shares. Gradually shift more funding towards secondary schools now that universal basic education has effectively been achieved.

- Focus on improving education quality with more controls on teachers' activities and on school management. Provide teachers with lifelong training, and review the certification programme.

- Take measures to restrain staff compensation as a share of education expenditures. Limit the number of small schools, develop multi-grade teaching, and use massive open online courses when appropriate.

- Improve health infrastructure, especially in Java. Encourage private-sector participation, but avoid creating a two-tier health system by requiring private hospitals to treat patients from the public scheme.

- Focus on those specific weaknesses in Indonesians' health outcomes that have high economic costs, like the fight against child malnutrition and stunting.

- Streamline social assistance and integrate social security payments with the income tax system. Boost funding for the most efficient measures, such as conditional cash transfers. Continue efforts to create a unified database of beneficiaries. Envisage a unique ID system to facilitate its management and updates.

\section{REFERENCES}

Analytical and Capacity Development Partnership (ACDP) (2013), "Madrasah Education Financing in Indonesia", Education Sector Analytical and Capacity Development Partnership, Policy Brief, September. 
ACDP (2014), "Teacher Absenteeism in Indonesia", Education Sector Analytical and Capacity Development Partnership, Policy Brief, November.

Appelt, S. and F. Galindo-Rueda (2016), "Measuring the Link between Public Procurement and Innovation", OECD Science, Technology and Industry Working Papers, 2016/03, OECD Publishing. http://dx.doi.org/10.1787/5jlvc7s11w7h-en

Armas, E., C. G. Osorio, B. Moreno-Dodson and D. Abriningrum (2012), “Agriculture Public Spending and Growth in Indonesia", Policy Research Working Paper, No. 5977, World Bank, February.

Banerjee, A., R. Hanna, J. Kyle, B. Olken and S. Sumarto (2015), "Contracting-out the Last-mile of Service Delivery: Subsidized Food Distribution in Indonesia”, NBER Working Paper, No. 21837.

Bayer, R., H. Oberhofer and H. Winner (2014), "The occurrence of tax amnesties: theory and evidence", Oxford University, Centre for Business Taxation, Working Paper, 14/02, January.

Beaton, C., L. Christensen and L. Lontoh (2015), “An Input to Indonesian Fuel Price System Reforms - a review of international experiences with fuel pricing systems", The International Institute for Sustainable Development, March.

Berg, A., E. Buffie, C. Pattillo, G. Portillo, A. Presbitero and L. Zanna (2015), "Some Misconceptions about Public Investment Efficiency and Growth", IMF Working Paper, WP/15/272, December.

Bhattacharyay, B., M. Kawai and R. Nag (2012), Infrastructure for Asian Connectivity, joint publication of the Asian Development Bank Institute and Asian Development Bank, Edward Elgar.

Blöndal, J., I. Hawkesworth and H. Choi (2009), "Budgeting in Indonesia”, OECD Journal on Budgeting Vol. 9/2, OECD Publishing. http://dx.doi.org/10.1787/budget-9-5ks72wv89p48

Blum, N. and R. Diwan (2007), "Small, Multigrade Schools and Increasing Access to Primary Education in India: National Context and NGO initiatives", Create Pathways to Access, Research Monograph, No.17.

Chang, M., S. Shaeffer, S. Al-Samarrai, A. Ragatz, J. de Ree and R. Stevenson (2014), Teacher Reform in Indonesia - The Role of Politics and Evidence in Policy Making, World Bank.

Coady, D., V. Flamini and L. Sears (2015), “The Unequal Benefits of Fuel Subsidies Revisited: Evidence for Developing Countries", IMF Working Paper, WP/15/250, November.

CONEVAL (2015), "Evaluaciòn de Diseño Programa de Apoyo Alimentario", Consejo Nacional de Evaluaciòn de la Politica de Desarollo Social, Clave Presupuestaria: S118.

Curristine, T., Z. Lonti and I. Joumard (2007), "Improving Public Sector Efficiency: Challenges and Opportunities", OECD Journal on Budgeting, Vol. 7/1, OECD Publishing. http://dx.doi.org/10.1787/budget-v7-art6-en

Dawe, D. (2013), "Geographic determinants of rice self-sufficiency in Southeast Asia", ESA Working Paper, Food and Agriculture Organisation, No. 13-03, June. 
de Ree, J. (2016), "How Much Teachers Know and How Much it Matters in Class: Analysing Three Rounds of Subject-specific Test Score Data of Indonesian Students and Teachers", Policy Research Working Paper, No. 7556, World Bank, February.

Economist Intelligence Unit (2015), "Universal Healthcare Coverage in Indonesia - One year on", The Economist Intelligence Unit Publishing, January.

Égert, B., T. Koźluk and D. Sutherland (2009), "Infrastructure and Growth: Empirical Evidence", OECD Economics Department Working Papers, No. 685, OECD Publishing. http://dx.doi.org/10.1787/225682848268

EY (2015), Ripe for Investment: the Indonesian Health Care Industry Post Introduction of Universal Health Coverage, Ernst \& Young.

Fadliya and R. McLeod (2010), "Fiscal Transfers to Regional Governments in Indonesia", Working Papers in Trade and Development, No. 2010/14, Australian National University, December.

Fall, F., D. Bloch, J. Fournier and P. Hoeller (2015), "Prudent debt targets and fiscal frameworks", OECD Economic Policy Papers, No. 15, OECD Publishing. http://dx.doi.org/10.1787/5jrxtjmmt9f7-en

Flyvbjerg, B., N. Bruzelius and W. Rothengatter (2003), Megaprojects and Risk: an Anatomy of Ambition, Cambridge University Press.

Fournier, J. and A. Johansson (2016), "The Effect of the Size and the Mix of Public Spending on Growth and Equity", OECD Economics Department Working Papers, forthcoming.

Ganelli, G. and J. Tervala (2015), “The Welfare Multiplier of Public Infrastructure Investment”, IMF Working Paper, WP/16/40.

Garcia-Jaramillo, S. and R. Maranti (2015), "Effectiveness of targeting in social protection programs aimed to children: lessons for a post-2015 agenda", Background paper for UNESCO (2015), EFA Global Monitoring Report 2015.

Global Business Guide (2013), “An Overview of Indonesia's Health Insurance Sector”, http://www.gbgindonesia.com/en/finance/article/2012/an_overview_of_indonesia_s_health_insuranc e_sector.php.

Granado, J., D. Coady and R. Gillingham (2010), "The Unequal Benefits of Fuel Subsidies: A Review of Evidence for Developing Countries", IMF Working Paper, WP/10/02, September.

Guerard, Y., M. Wiener, C. Rokx, G. Schieber, P. Harimurti, E. Pambudi and A. Tandon (2011), "Actuarial Costing of Universal Health Insurance Coverage in Indonesia - Options and Preliminary Results", Health, Nutrition and Population (HNP) Discussion Paper, World Bank, April.

Hidayat, B. (2015), "Financial Sustainability of the National Health Insurance in Indonesia: a First Review", Policy Brief, Indonesian-German Social Protection Programme (SPP), November.

Hidayat Putra, T., J. Woltjer and W. Tan (2015), "Decentralization and Governance for Sustainable Society in Indonesia", in R. Holzhacker, R. Wittek and J. Woltjer (eds.), Decentralization and Governance in Indonesia, Springer. 
Hoddinott, J., H. Alderman, J. Behrman, L. Haddad and S. Horton (2013), "The economic rationale for investing in stunting reduction", Maternal \& Child Nutrition, Vol. 9, Issue Supplement S2, September.

Holzhacker, R., R. Wittek and J. Woltjer (2015), "Decentralization and Governance for Sustainable Society in Indonesia", in R. Holzhacker, R. Wittek and J. Woltjer (eds.), Decentralization and Governance in Indonesia, Springer.

International Monetary Fund (IMF ) (2015), Making Public Investment More Efficient, IMF Staff Report, June.

Indonesia Investments (2016), "Indonesia's National Health Insurance Program: Rising Financial Mismatch”, 3 March http://www.indonesia-investments.com/news/todays-headlines/indonesia-snational-health-insurance-program-rising-financial-mismatch/item6563.

Jakarta Post (2015), “Confusing fuel-price policies”, Editorial, 30 December.

Joumard, I., C. André and C. Nicq (2010), "Health care systems: efficiencies and institutions", OECD Economics Department Working Paper, No. 769, OECD Publishing. http://dx.doi.org/10.1787/5kmfp51f5f9t-en

Knox Lovell, C. (2002), "Performance Assessment in the Public Sector", in K. J. Fox (ed.), Efficiency in the Public Sector, Springer and Business Media, New York.

Komisi Pemberantasan Korupsi (KPK) (2014), "Local Government Performance Mineral and Coal Evaluation", Mining Anti-Mafia Coalition, http://acch.kpk.go.id/documents/10180/990027/04+Indeks+Kinerja+Pemda+Korsup+Miner ba-KoalisiAntiMafiaTambang.pdf/b1870e76-867b-4459-bf80-f728bc653281

KPK (2016), “Realize Energy Sovereignty”, http://www.kpk.go.id/id/berita/siaran-pers/3241-kpkgandeng-32-provinsi-wujudkan-kedaulatan-energi

Lewis, B. (2014a), “Twelve years of fiscal decentralization: a balance sheet”, in H. Hill (ed.), Regional Dynamics in a Decentralised Indonesia, Institute of Southeast Asian Studies, Singapore.

Lewis, B. (2014b), “Intergovernmental Performance Grants: An Empirical Assessment of Impact”, Bulletin of Indonesian Economic Studies, Vol. 50, No.3.

Lewis, B. and D. Pattinasarany (2011), "The Cost of Public Primary Education in Indonesia: Do Schools Need More Money?", Education Economics, Vol.19, No.4.

Lewis, B., N. McCulloch and A. Sacks (2015), "Measuring Local Government Service Delivery Performance: Challenges and (partial) Solutions in Indonesia", Journal of International Development, 27 May.

Lewis-Faupel, S., Y. Neggers, B. Olken and R. Pande (2016), "Can Electronic Procurement Improve Infrastructure Provision? Evidence from Public Works in India and Indonesia", American Economic Journal: Economic Policy, Vol. 8, No. 3.

Lustig, N. (2015), "Inequality and Fiscal Redistribution in Middle Income Countries: Brazil, Chile, Colombia, Indonesia, Mexico, Peru and South Africa", CEQ Working Paper, No. 31, Commitment to Equity, July. 
Martinez-Vazquez, J. and F. Vaillancourt (2011), Decentralization in Developing Countries - Global Perspectives on the Obstacles to Fiscal Devolution, Edward Elgar.

Marzoeki, P., A. Tandon, X. Bi and E. Pambudi (2014), Universal Health Coverage for Inclusive and Sustainable Development, Japan-World Bank.

McCulloch, N. (2008), "Rice Prices and Poverty in Indonesia", Bulletin of Indonesian Economic Studies, Vol. 44, No. 1.

McGuire, J. (2006), "Basic Health Care Provision and Under-5 Mortality: a Cross-National Study of Developing Countries", World Development, Vol. 34, No. 3, March.

Ministry of Finance (2015), “Book II: Financial Note and Budget - Fiscal Year 2016”, Budget Directorate.

Nurmandi, A. (2013), "What is the Status of Indonesian E-Procurement?", Working Paper, Universitas Muhammadiyah, Yogyakarta.

Nurmandi, A. and S. Kim (2015), "Making E-Procurement Work in a Decentralized Procurement System a Comparison of Three Indonesian Cities", International Journal of Public Sector Management, Vol. 28, No. 3 .

OECD (2002), Foreign Direct Investment for Development - Maximising Benefits, Minimising Costs, OECD Publishing. http://dx.doi.org/10.1787/9789264199286-en

OECD (2007), "Snapshot Assessment of Indonesia's Public Procurement System - Piloting OECD/DAC Procurement JV - Baseline Indicator (BLI) Benchmarking Methodology Version 4", June.

OECD (2012a), "Recommendation of the Council on Principles for Public Governance of Public-Private Partnerships", www.oecd.org/gov/budgeting/PPP-Recommendation.pdf, May.

OECD (2012b), "Public-private partnership governance: Policy, process and structure", OECD Reviews of Regulatory Reform: Indonesia 2012: Strengthening Co-ordination and Connecting Markets, OECD Publishing.

http://www.oecd.org/gov/regulatory-policy/Chap\%206\%20PPPs.pdf

OECD (2013a), A Step Change in Tax Transparency: Delivering a Standardised, Secure and Cost Effective Model of Bilateral Automatic Exchange for the Multilateral Context, OECD report for the G8 Summit, June.

OECD (2013b), “What drives tax morale?", Tax and Development, March. http://dx.doi.org/10.1787/5k8zk8m61kzq-en

OECD (2015a), OECD Economic Surveys: Indonesia, OECD Publishing. http://dx.doi.org/10.1787/eco_surveys-idn-2015-en

OECD (2015b), Fostering Investment in Infrastructure, OECD Publishing. https://www.oecd.org/daf/inv/investment-policy/Fostering-Investment-in-Infrastructure.pdf

OECD (2015c), OECD Guidelines on Corporate Governance of State-Owned Enterprises, 2015 Edition, OECD Publishing.

http://dx.doi.org/10.1787/9789264244160-en 
OECD (2015d), OECD Economic Surveys: Brazil, OECD Publishing. http://dx.doi.org/10.1787/eco_surveys-bra-2015-en

OECD (2015e), Transfer Pricing Documentation and Country-by-Country Reporting, Action 13 - 2015 Final Report, OECD/G20 Base Erosion and Profit Shifting Project, OECD Publishing. http://dx.doi.org/ 10.1787/9789264241480-en.

OECD (2015f), Update on Voluntary Disclosure Programmes: A Pathway to Tax Compliance, OECD Publishing. http://www.oecd.org/ctp/exchange-of-tax-information/update-on-voluntary-disclosure-programmesa-pathwaypto-tax-compliance.htm

OECD (2016a), Open Government in Indonesia, OECD Publishing, forthcoming.

OECD (2016b), Skills Matter - Further Results from the Survey of Adult Skills, OECD Publishing. http://dx.doi.org/10.1787/9789264258051-en

OECD (2016c), Economic Surveys; Indonesia 2016, OECD Publishing. www.oecd.org/eco/surveys/economic-survey-indonesia.htm

OECD/Asian Development Bank (2015), "Education in Indonesia - Rising to the Challenge", Reviews of National Policies for Education, OECD Publishing. http://dx.doi.org/10.1787/9789264230750-en

Patunru, A. and E. Rahman (2014), "Local governance and development outcomes", in H. Hill (ed.), Regional Dynamics in a Decentralised Indonesia, Institute of Southeast Asian Studies, Singapore.

Pradiptyo, R. (2016), “Corruption Analytics Database Report”, http://ugm.ac.id/en/news/11457politicians.and.private.sector.most.corrupt, University Gadjah Mada, 5 April.

Reuters (2016), "Subsidy sham: Fertilizers reach Indonesia plantations, not small farmers", 14 February http://www.reuters.com/article/us-indonesia-fertilizers-idUSKCNOVN127.

Rokx, C., G. Schieber, P. Harimurti, A. Tandon and A. Somanathan (2009), Health Financing in Indonesia - a Reform Roadmap, World Bank.

Shah, A., R. Qibthiyyah and A. Dita (2012), “General Purpose Central-Provincial-Local Transfers (DAU) in Indonesia - from gap filling to ensuring fair access to essential public services for all”, Policy Research Working Paper, No. 6075, World Bank.

Shrimpton, R. and C. Rokx (2013), The Double Burden of Malnutrition in Indonesia, World Bank, Jakarta.

Silitonga, M., G. Anthonio, L. Heyse and R. Wittek (2015), "Institutional Change and Corruption of Public Leaders: A Social Capital Perspective on Indonesia", in R. Holzhacker, R. Wittek and J. Woltjer (eds.), Decentralization and Governance in Indonesia, Springer.

Suharti (2013), "Trends in education in Indonesia", in D. Suryadarma and G. W. Jones (eds.), Education in Indonesia, Institute of Southeast Asian Studies, Singapore.

Suryadarma, D. (2012), "How Corruption Diminishes the Effectiveness of Public Spending on Education in Indonesia", Bulletin of Indonesian Economic Studies, Vol. 48, No. 1, April. 
Swiss Federal Council (2014), Rapport sur l'évaluation de l'efficacité 2012-2015 de la péréquation financière entre la Confédération et les cantons, Conseil fédéral, Confédération suisse.

Tim Nasional Percepatan Penanggulangan Kemiskinan (TNP2K) (2015), "Indonesia's Unified Database for Social Protection Programmes - Management Standards", National Team for the Acceleration of Poverty Reduction, July.

Toft, L., C. Beaton and L. Lontoh (2016), "International Experiences with LPG Subsidy Reform - Options for Indonesia", International Institute for Sustainable Development, January.

Trimurni, F., A. Siahaan and Dayana (2015), "E-Procurement Policy Model: Case Study of Health Agency in North Sumatra Province, Indonesia", Public Policy and Administration Research, Vol. 5, No. 11.

United Nations (2009), Public Investment: Vital for Growth and Renewal, but Should it be a Countercylical Weapon?, United Nations, New York and Geneva.

Vujanovic (2017), "Decentralisation to promote regional development", OECD Economics Department Working Papers, forthcoming.

Wagstaff, A., D. Cotlear, P. Eozenou and L. Buisman (2015), "Measuring Progress Towards Universal Health Coverage - with an application to 24 Developing Countries", Policy Research Working Paper, No. 7470, November, World Bank.

World Bank (2010), "Investing in Multi-Grade Teaching in Indonesia", Policy Brief, November.

World Bank (2012a), Indonesia Subnational Public Expenditure Review - Optimizing Subnational Performance for Better Services and Faster Growth, World Bank.

World Bank (2012b), "Investing in Indonesia's Roads - Improving Efficiency and Closing the Financing Gap", Road Sector Public Expenditure Review, Jakarta and Washington DC.

World Bank (2012c), "PKH Conditional Cash Transfer", Social Assistance Program and Public Expenditure Review, 6/67309, Washington DC.

World Bank (2013a), Beyond the Annual Budget - Global Experience with Medium-Term Expenditure Frameworks, World Bank, Washington.

World Bank (2013b), Spending More or Spending Better: Improving Education Financing in Indonesia, World Bank.

World Bank (2014), "Fiscal Policy and Redistribution in an Unequal Society", South Africa Economic Update, World Bank.

World Bank (2015), Indonesia - Connecting the Bottom 40 Percent to the Prosperity Generation, World Bank.

World Economic Forum (2016), The Global Competitiveness Report 2016-2017, Geneva. 